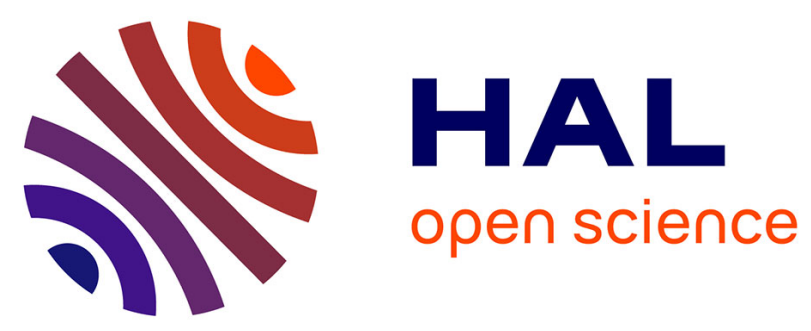

\title{
Refining the high-fidelity archaeointensity curve for western Europe over the past millennium: analysis of Tuscan architectural bricks (Italy)
}

Agnes Genevey, Claudia Principe, Yves Gallet, Giuseppe Clemente, Maxime

Le Goff, Alexandre Fournier, Pasquino Pallecchi

\section{To cite this version:}

Agnes Genevey, Claudia Principe, Yves Gallet, Giuseppe Clemente, Maxime Le Goff, et al.. Refining the high-fidelity archaeointensity curve for western Europe over the past millennium: analysis of Tuscan architectural bricks (Italy). The Geological Society, London, Special Publications, 2019, 497 (1), pp.73-88. 10.1144/SP497-2019-74 . hal-03028885

\section{HAL Id: hal-03028885 https://hal.science/hal-03028885}

Submitted on 27 Nov 2020

HAL is a multi-disciplinary open access archive for the deposit and dissemination of scientific research documents, whether they are published or not. The documents may come from teaching and research institutions in France or abroad, or from public or private research centers.
L'archive ouverte pluridisciplinaire HAL, est destinée au dépôt et à la diffusion de documents scientifiques de niveau recherche, publiés ou non, émanant des établissements d'enseignement et de recherche français ou étrangers, des laboratoires publics ou privés. 
1 Refining the high-fidelity archaeointensity curve for Western Europe over the past

millennium: Analysis of Tuscan architectural bricks (Italy)

3

Agnès Genevey, Sorbonne Université, CNRS, Laboratoire d'Archéologie Moléculaire et Structurale, LAMS, 4 place Jussieu, F-75005 Paris, France.

Claudia Principe, Istituto di Geoscienze e Georisorse, Area della Ricerca CNR, Via G. Moruzzi 1, 56124 Pisa, Italy \& IGG-CNR Archaeomagnetic Dating Laboratory (ARCHAEO-Lab), Villa Borbone, Viareggio, Italy

Yves Gallet, Université de Paris, Institut de Physique du Globe de Paris, CNRS, 1 rue Jussieu, F-75005 Paris, France

Giuseppe Clemente, Independent researcher, via vittorio Galluzzi 8, I-56124 Pisa, Italy

Maxime Le Goff, Université de Paris, Institut de Physique du Globe de Paris, CNRS, 1 rue Jussieu, F-75005 Paris, France

Alexandre Fournier, Université de Paris, Institut de Physique du Globe de Paris, CNRS, 1 rue Jussieu, F-75005 Paris, France

Keywords: Archaeomagnetism, Archaeointensity, Palaeomagnetic secular variation, Italy,

Western Europe, Past Millennium

\section{Abstract}

24 New archaeointensity results were obtained from fourteen groups of baked-brick fragments 25 collected in and around Pisa (Tuscany, Italy). The fragments were assembled from civil and 
religious buildings whose dating of construction or renovation, over the past millennium, was constrained by documentary sources. This collection, analysed using the Triaxe protocol, was found particularly suitable for intensity experiments, with a success rate of $\sim 84 \%$ corresponding to 276 fruitful specimens associated to 125 independent brick fragments. The Tuscan data clearly show a peak in intensity at the transition between the 16th and 17th centuries. They also are in very good agreement and are complementary to a dense dataset previously obtained in France. Considering the results available within a $700 \mathrm{~km}$ radius of Beaune (between Paris and Pisa), all satisfying a set of quality criteria, a mean geomagnetic field intensity variation curve was constructed for the past millennium using a newly developed transdimensional Bayesian technique. This curve, which thus incorporates the new Tuscan results, allows a better recognition of three intensity peaks (during the twelfth, the fourteenth, and around AD 1600) in Western Europe. The detail of this curve is a clear illustration of the centennial-scale resolution that can be achieved using accurate archaeointensity data.

\section{Introduction}

Due to its active volcanoes and particularly rich cultural heritage, Italy can certainly be viewed as a privileged "playground" for palaeomagnetists to trace back recent variations of the Earth's magnetic field. Analysis of lava and pyroclastic flows emitted by Italian volcanoes has enabled important steps in understanding and describing the main lines of the geomagnetic directional variations over the past few millennia (e.g. Tanguy et al., 1999, 2003, 2007, 2012; Principe et al. 2004; Arrighi et al. 2006; Vezzoli et al. 2009; Branca et al. 2015a). Additionally, these studies further allowed re-dating of some lava flows - in the case of Mount Etna and Vesuvius, these archaeomagnetic constraints were ultimately incorporated 
for drawing their respective most recent geological map, underlining the potential of such studies for the comprehension of volcanic edifices (Branca et al. 2015b; Paolillo et al., 2016)

On the other hand, during the past 15 years or so, there has been in Italy a dynamic development of archaeomagnetic research sensu stricto. New archaeodirectional data were acquired from in situ fired structures, which, together with volcanic data, have allowed a continuous and accurate description of the main lines of the geomagnetic directional variations in the Italian Peninsula from 1200 BC onwards (see the compilation of Tema et al. 2006 updated in 2011 by Tema, and new results acquired since then: Malfatti et al. 2011; Kapper et al. 2014; Tema et al. 2016).

In contrast, archaeointensity data in Italy remains very few, despite recent progress. Only 31 results are currently available for a large time interval of eight millennia, with a quite uneven temporal distribution (Evans 1986, 1981; Aitken et al. 1988; Hedley and Wagner 1991; Hill et al. 2007, 2008; Donadini and Pesonen 2007; Gallet et al. 2009; Tema et al. 2010, 2013, 2016 see also Tema et al. 2011). A few other archaeointensity results were obtained in Italy, but they mostly relied on archaeomagnetic dating, and for this reason they were not further considered in this study (e.g. Tema et al. 2015; Principe et al. 2018). Most of the available results (21) are dated between the 3rd century BC and the 8th century AD, with a strong concentration of data (12) between 100 BC and AD 100. Three archaeointensity results were recently obtained for the Early Neolithic period (c. 7500 years ago; Tema et al. 2016), two results are dated for the 8th century $\mathrm{BC}$ and the five remaining results of 31 document the past five centuries. New archaeointensity data are thus required before a full description of the geomagnetic field variations in Italy over the past two to three millennia can be achieved.

This study aims to contribute to this long-term project with the archaeointensity analysis of groups of brick fragments collected in and around Pisa. Fourteen brick buildings dated from between the middle of the 12th century and the end of the 17 th century were 
sampled. From a broader geomagnetic perspective, this study also addresses the issue of the maximum time resolution of the recording of the geomagnetic field intensity variations accessible from archaeomagnetic data. This is particularly important as several short-term (maximum of two centuries) intensity peaks have been proposed over the past millennium in Western Europe from a dense set of French data (Genevey et al. 2009, 2013, 2016). The intensity variation rates associated with these peaks are quite strong $(\sim 0.10 \mu \mathrm{T} / \mathrm{yr})$, similar to the maximum rate observed in the recent field (e.g. Livermore et al., 2014).

\section{Description of the historical baked-brick buildings investigated}

Since the Middle Ages, Pisa and its province have been an important area in Tuscany for ceramic production, particularly using clay from the Arno River and the Serchio River (Clemente 2015, 2017). Bricks are still produced in Pisa, and numerous buildings made of bricks were built during the past eight centuries of Pisa's history.

Our sampling focused on the baked-brick architectural heritage of the city of Pisa and its neighbouring territory, encompassing almost five and a half centuries, from the middle of the 12 th century to the end of the 17 th century. It thus explores the history of Pisa from its apogee as a maritime and commercial power to its decline at the end of the 13th century, followed by a lengthy period under the domination of Florence.

We selected a series of fourteen ensembles of bricks based on careful analysis of available historical and archaeological data, incorporating documentary, iconographic and cartographic sources. In one case, the year of inauguration was directly inscribed on the building (Figure 1a,b). All bricks were collected from important buildings commissioned by the political and/or religious authorities. Even though the year of construction/inauguration of such buildings do not necessarily correspond exactly to the year of production of the bricks, it is nevertheless certain that the time lag between their production and their use was very short 
100 (most probably less than a year). According to historical and archaeological evidence, the

101 bricks used were produced specifically for each construction and were not recycled, also

102 because the quantities of bricks required were extremely high. Furthermore, in order to avoid

103 the sampling of possibly re-used bricks, we have taken great care to take all our samples from

104 parts of the walls characterized by homogeneous bricks in terms of colour, aspect, and

105 dimension. No damaged brick, particularly with traces of burning or chipped portions, were

106 sampled. In addition, to ensure that the sampled bricks had a size characteristic of the

107 expected period, we used mensiochronology, a chronological tool based on the temporal

108 evolution of brick size (e.g. Quiros Castillo 1997). Although this tool requires improvement,

109 it was observed that the thickness of the bricks gradually decreased from $\sim 6 \mathrm{~cm}$ around 1200

110 to $\sim 4 \mathrm{~cm}$ at $\sim 1700$ (Quiros Castillo 1997). Furthermore, our selection of sites was dictated by

111 their accessibility to our sampling (Table 1). This sampling was performed using a portable

112 driller. Between 10 and 16 cores were taken per group, and the holes were later filled with

113 tinted mortar in order to restore the visual aspect of the sampled walls as much as possible

114 (Figure 1c,d,e).

115 Nine groups were collected in Pisa. The two oldest (Pise11 and Pise12) are from the medieval 116 ramparts built between the middle of the 12th century and the 14th century. These are largely

117 preserved and still partly surround the historical centre of the city. Drilling was performed on

118 the same wall located on the edge of the present Scotto Garden (south bank of the Arno

119 River), where two different phases of construction of the rampart are observed (Gattiglia and

120 Milanese, 2006). The construction of this medieval wall was initiated in AD 1155 and the

121 bricks of group Pise12 document this first phase, as confirmed by their thickness, between 6.5

122 and $7.5 \mathrm{~cm}$, larger than the one observed since. The second, more recent, sampled phase

123 (Pise11) dates from the first half of the 14th century - i.e., the end of the construction of the

124 city wall (Quiros Castillo 1997). 
Two groups were sampled in the Florentine fortress located in the same area of the

126 Scotto Garden. This large building was erected during the middle of the 15th century (AD

127 1440), after the end of the Pisan Republic and under Florentine domination (Gattiglia and Milanese 2006). The first group of samples (Pise10) collected in the Santa Barbara tower (northern part of the fortress) dates from its construction, whereas the second group from the

130 Sangallo bastion (Pise09; north-western part near the Florentine bridge over the Arno River, 131 inside the Corsini building) corresponds to a renovation phase, during AD 1531-1533, which 132 occurred after a short period of revolt in Pisa and its subsequent reconquest by Florence. 133 Another group (Pise02) was collected from the Oratory of San Bernardino, which was built at 134 the end of the 15th century to ward off epidemics of medieval plague (Sodi and Radi 1979). In addition to group Pise09, three other archaeomagnetic groups allow us to document the 16th century. Group Pise01 was collected from the hydraulic regimentation structure of the 'Bocchette', positioned at the entrance of a canal built during the years of Cosimo I de'

138 Medici's government and located a little to the east of the city (Figure 1a,b). This structure 139 was constructed to divert excess waters of the Arno River towards the Pisan plain, thus 140 avoiding devastating flooding inside the city (Ciuti 2003). Group Pise08 was sampled in the 141 important structure of the Medici arsenal, built between 1543 and 1563 on the banks of the 142 Arno River towards its mouth (Ciuti 2003). Our sampling concerns a well-known renovation 143 phase carried out few years later in 1588. The third group (Pise06) was sampled in the

144 structure of the Medici aqueduct, the construction of which was decided upon by Grand Duke 145 Ferdinando I de' Medici. This aqueduct provided Pisa with fresh and drinkable water from the 146 source, located near the little town of Asciano in the Monti Pisani area (Gasperini et al. 2015).

147 This archaeomagnetic fragment group was collected in a pillar of the terminal segment of the 148 structure. 
In Pisa, the 17th century is represented by a group of fragments collected from the

150 Santo Stefano Dei Cavaleiri church located in the city centre. Although it was founded around

151 the middle of the 16th century under the direction of Cosimo I de' Medici, some parts of its

152 external walls are more recent and precisely date to 1683-1691 (Sodi and Renzoni 2003),

153 where archaeomagnetic group Pise07 comes from.

154 Five more groups of fragments were collected in the province of Pisa. The first group

155 (Tosc03) dates from the second half of the 13th century and was sampled in a tower of the

156 castle of Calcinaia, a small medieval city of the Pisan plain along the Arno River (17 km from

157 Pisa), that was built and fortified by the Pisans (Alberti and Baldassarri 2004). A second

158 group (Tosc04) was precisely dated to 1331, as ascertained by archives, and was drilled in the

159 external wall of the church of Marti in the municipality of Montopoli Valdarno (Febbraro

160 2006). Finally, three archaeomagnetic fragment groups were also sampled in other segments

161 of the Medici aqueduct dated to slightly more recent ages (first half of the 17 th century) than

162 group Pise06 located in Pisa, because of later construction and/or a renovation. Group Pise03

163 comes from the start of the aqueduct (cistern of Ascabo Pisano, Figure 1c), while Pise04 and

164 Pise05, drilled from the arch, come from intermediate but close segments along its path.

A total of 179 cores were drilled from the 14 archaeomagnetic sites described above,

166 and they were subjected to archaeointensity experiments.

\section{Archaeomagnetic investigation and brick composition}

The intensity experiments were carried out using three Triaxe magnetometers housed

170 at the paleomagnetic laboratory of the Institut de Physique du Globe de Paris (IPGP), of

171 which one belongs to the Laboratoire d'Archéologie Moléculaire et Structurale (LAMS).

172 The Triaxe protocol has been specially designed to take advantage of the specificities

173 of this equipment, which allows the three magnetisation components of a small specimen 
174 (less than $1 \mathrm{~cm}^{3}$ in volume) to be measured continuously up to high temperatures, either in a 175 zero field or in a laboratory field, whose intensity and direction are controlled (Le Goff and 176 Gallet, 2004).

177 This procedure, derived from the Thellier and Thellier (1959) method, was detailed in 178 previous papers (e.g. Gallet and Le Goff 2006; Genevey et al. 2009; Hartmann et al. 2010).

179 Table 2 summarises the five heating and cooling steps involved in the Triaxe procedure, 180 which are carried out between a low temperature, $\mathrm{T} 1$ (between $110{ }^{\circ} \mathrm{C}$ and $150{ }^{\circ} \mathrm{C}$ ), and a 181 high temperature, T2, chosen such that a large part of the natural remanent magnetization 182 (NRM) is involved. Here, T2 was fixed between $400{ }^{\circ} \mathrm{C}$ and $450{ }^{\circ} \mathrm{C}$, as almost total 183 demagnetisation was achieved at this temperature.

184 The ancient geomagnetic field intensity is inferred from the series of measurements of steps \#1,\#3 and \#5 (with increasing temperatures) - more precisely, from the averaging of the R'(Ti) data computed over the temperature range where the primary component is isolated. Each R'(Ti) value is equal to the ratio, multiplied by the applied laboratory field intensity, 188 between the demagnetised fractions of NRM (step \#1) and thermoremanent magnetisation 189 (TRM; step \#5) between T1 and Ti, with both fractions being corrected from the thermal variations of the NRM fraction still blocked at T2 (step \#3) (see discussion in Le Goff and

191 Gallet 2004). When a second component is observed, the R'(Ti) data are computed from a 192 higher temperature referred to as T1' up to T2.

It should be emphasised that this protocol takes into account the anisotropy of the 194 thermoremanent magnetisation since the laboratory field direction is automatically chosen so 195 as to induce a TRM parallel to the original NRM (Le Goff and Gallet 2004). Additionally, it 196 was experimentally observed that the Triaxe protocol allows the cooling-rate effect to be 197 overcome when the intensity values are derived from the R'(Ti) data. This characteristic was 198 verified for different archaeological collections of various ages and origins from the Near 
199 East, Europe, Russia and Brazil (Le Goff and Gallet 2004; Genevey et al. 2009, 2013;

200 Hartmann et al. 2010; Hervé et al. 2017; Salnaia et al. 2017). Finally, it is worth noting that an

201 effect of multidomain grains (if any) would be mitigated with this protocol since the

202 laboratory magnetisation acquired from T2 is almost a full TRM.

203

The Triaxe results were assessed on the basis of selection criteria presented in

204 Supplementary Table 1 (see also e.g. Genevey et al. 2016). Firstly, they allow us to judge the quality of the determination at the specimen level, checking both the directional and intensity behaviours. Two specimens per fragment must then be successfully investigated, and their results must agree within a limit of $5 \%$. A mean value is computed at the site level when 208 deriving from at least three different fragments, and its standard deviation must be less than 5 $209 \mu \mathrm{T}$ and $10 \%$ to be retained. The consistency of the results is thus tested at both the fragment and group levels. The relevance of these criteria, and those related to the selection of archaeological artefacts, was in fine further tested through the consistency of the intensity values obtained between sites of similar age.

For those groups of fragments successfully analysed for intensity, the magnetic mineralogy was explored through progressive thermal demagnetisation of three orthogonal isothermal remanent magnetization (IRM) acquired on cubic specimen (of side $1 \mathrm{~cm}$ ) in high (1.5 T), medium (0.4 T) and low (0.2 T) fields (Lowrie 1990). The IRM was imparted using a MMPM10 pulse magnetiser, while the magnetisation measurements were carried out using a 218 JR-6 spinner (Agico) magnetometer. One fragment per site was subjected to these experiments. In addition, magnetic susceptibility measurements were performed for at least two fragments per site along a heating-cooling cycle between $20{ }^{\circ} \mathrm{C}$ and a high temperature

221 chosen close to temperature T2 considered for the Triaxe experiments (here $400{ }^{\circ} \mathrm{C}-450{ }^{\circ} \mathrm{C}$ ). 222 These experiments aimed to confirm the thermal stability of the magnetic mineralogy on the 223 same temperature range involved in the intensity analysis. The measurements were performed 
using a KLY-3 Kappabridge coupled to a CS3 unit (Agico). Note that in our previous studies

(e.g. Hartmann et al. 2011; Genevey et al. 2016), these experiments were systematically conducted on all the fragments retained in intensity. Here, this has not been the case because

227 the magnetic susceptibility versus temperature curves were found to be almost identical for 228 the entire collection (see below).

Brick fragments were further analysed in the laboratory of the Archaeological

230 Superintendence of Florence in order to define their composition. After a first description by

231 means of a Nikon SMZ800 stereo-microscope, thin sections of about $30 \mu \mathrm{m}$ were analysed

232 using a Leitz Ortoluz POL polarising microscope connected to a DIGIMAT image processor

233 in order to define their petrographic paragenesis and textures, and microanalyses were also

234 carried out using an FEI Quanta 200 electronic microscope connected to a EDX Edax DX-4

235 spectrometer in order to explore the chemical composition variability.

\section{4. Results}

239 One important feature of this collection of brick fragments is its remarkable 240 homogeneity in terms of paleomagnetic behaviour. This behaviour is characterised by an 241 almost total thermal demagnetisation of the NRM at relatively low temperatures - i.e., around $242400{ }^{\circ} \mathrm{C}-450{ }^{\circ} \mathrm{C}$, with a single magnetization component isolated from $135^{\circ} \mathrm{C}-220^{\circ} \mathrm{C}$ up to the 243 highest temperatures (Supplementary Table 2). This collection also appears to be very 244 suitable for intensity experiments. Indeed, of the 149 fragments investigated using the Triaxe 245 magnetometers, only 24 fragments were rejected, leading to a very good success rate of $84 \%$

246 (Supplementary Table 2). For 11 groups of fragments, this percentage ranges from $80 \%$ to $247100 \%$ at the group level, while it is more modest, between $45 \%$ and $55 \%$, for the other three 248 groups. It is worth noting that these percentages refer to the fragments whose magnetisation 
was strong enough in relation to the Triaxe sensitivity; 27 fragments were found to be too weakly magnetised. The retained specimens (Supplementary Table 2) possess a NRM between 30 and $70010^{-8} \mathrm{~A} \cdot \mathrm{m}^{2}$ with a NRM below $25010^{-8} \mathrm{~A} \cdot \mathrm{m}^{2}$ for $90 \%$ of the collection. For 14 fragments, failures in intensity experiments were linked to a non-ideal behaviour during the thermal treatment, as illustrated in Figure $2 \mathrm{a}$ by the Tosc04-04B specimen. For this specimen (and corresponding fragment), the R'(Ti) data decrease continuously all over the temperature interval investigated, although only one magnetisation component is observed (Figure 2b), which prevents the recovery of a reliable intensity of the ancient magnetic field. By contrast, the Pise04-05A specimen displays an appropriate behaviour for intensity determination, with quasi-constant $\mathrm{R}^{\prime}(\mathrm{Ti})$ data observed over the temperature range where the primary component is isolated (Figures $2 \mathrm{a}, \mathrm{c}$ ). The other reason for rejection is related to the non-fulfilled coherence test at the fragment level (10 fragments).

The very homogeneous magnetic behaviour above is associated with an almost 262 identical magnetic mineralogy for the whole collection of fragments (at least for the 263 fragments successfully analysed for intensity). The three-axis IRM curves show a systematic 264 predominance of low coercivity $(<0.2 \mathrm{~T})$ minerals, with unblocking temperatures ranging 265 from $450{ }^{\circ} \mathrm{C}$ to $600{ }^{\circ} \mathrm{C}$, which are likely to be from the magnetite family with impurities of 266 various contents (Figure 3). The thermal demagnetisation of the 1.5-T IRM also shows the 267 presence of a small fraction of high-coercivity minerals, likely being hematite. For some 268 fragments, we observe a fraction of minerals with unblocking temperatures below $200{ }^{\circ} \mathrm{C}-$ $269250{ }^{\circ} \mathrm{C}$ and high coercivity, which probably indicates the presence of epsilon iron oxide, as 270 recently identified by López-Sánchez et al. (2017, Figure 3). The susceptibility vs temperature 271 curves, although providing no additional information on the magnetic mineralogy, also 272 emphasise the homogeneity of the collection, as well as the thermal stability of the magnetic 273 mineralogy over the temperature range used for intensity determinations (inserts in Figure 3). 
274 This consistency in the magnetic response to all the experiments above is most probably due 275 to the use of the same raw material.

A total of 276 specimens associated to 125 brick fragments were successfully analysed

277 for intensity. This allowed 14 new mean well-defined intensity values (Table 1) to be derived.

278 This is illustrated in Figure 4, where each panel displays for one group all the results obtained 279 at the specimen level.

280 The homogeneity of this archaeological collection is further supported by petrographic and 281 spectrometric measurements. The original clayey material contains silicate debris attributable 282 to quartz in both single crystal and polycrystalline aggregate forms with a sub-angular to 283 angular morphology. There is no addition of sandy sediments, as would be the case if the 284 material source was along the course of the Arno River. The absence of fine silt and of well 285 rounded clasts also militate against a supply of clay from the small quarries that were active in 286 Pisa from at least the 13th century (Clemente 2015, 2017). On another hand, it should be 287 noted that the huge quantity of clay necessary for the construction of the large buildings 288 studied likely exceeded the resources of these small in-town quarries (Clemente 2015, 2017). 289 In contrast, the quartz and the other silicate (feldspars, micas) components are typical of 290 alluvial deposits coming from the eastern part of the Monti Pisani sedimentary succession 291 (Carratori et al., 1991). The sharped edges and the clasts typologies suggest a short transport 292 along small watercourses contributing to the paleo-course of the Serchio River.

293 All fragments have in common a red-coloured isotropic matrix due to iron oxidation, as well 294 as recrystallisation of calcium carbonate during the thermal processes, probably resulting 295 from the addition of limestone fragments to the clay to increase the porosity of the bricks and 296 reduce their weight. A fine granulometry is systematically observed in the limestone clasts, 297 which are present in variable quantities and evenly distributed in the matrix. The 298 microanalytical investigations show the same qualitative composition. All fragments appear 
to be made of clayey material fired in furnaces with excess oxygen (oxidising environment) at temperatures between $\sim 800{ }^{\circ} \mathrm{C}$ and $\sim 980{ }^{\circ} \mathrm{C}$. Comparison of the textural and compositional

301 characteristics of the bricks of Pisa with those of Calcinaia and Marti shows strong 302 similarities, except for the quantity of the limestone clasts.

303 Based on the results above, we suggest that the bricks used in huge quantity for the 304 construction of the studied buildings in Pisa were manufactured in the Calcinaia area, where 305 the presence of brick kilns since the 15th century (Alberti, 2015) is documented, and where 306 their transport to Pisa was easy thanks to the proximity of the Arno River.

\section{Discussion}

Our new data obtained in Tuscany are reported in Figure 5 together with the five other archaeointensity results available in Italy for the past millennium (Evans 1986; Aitken et al. 1988; Tema et al. 2010, 2013, Tema 2011, see also Figure 6 for their geographical

312 distribution). Alone, the Tuscan data show a decreasing trend in intensity from the middle of 313 the 12th century to c. 1500. There was then an increase until the beginning of the 17th 314 century, followed by a decrease in intensity for about a century. At this stage, it can be noted that the two other Italian data available for the time period (1500-1700) cannot be easily reconciled with this variation pattern. This could be the case, however, for the result with the widest dating interval if its true age would lie at either extremities of that interval. In contrast,

318 the three most recent data appear in good agreement with the direct measurements and/or the gufm1 model predictions at Pisa (Jacskon et al. 2000). other data available within a $900 \mathrm{~km}$ radius around Viterbo (central Italy) to construct an

322 intensity variation curve for the Italian peninsula. This curve is composed of two segments, 323 the ages of which range between 100BC and $\mathrm{AD} 400$, and $\mathrm{AD} 1300$ and $\mathrm{AD} 1800$, 
respectively. These two intervals are those where the data selected on the basis of quality criteria are sufficiently numerous. Interestingly, for the period of 1300-1800, the Italian curve is in fact largely determined from the data obtained in the south of France (e.g. Genevey et al. 2009). For this reason, to compare our new Tuscan data with the other results available regionally, we preferred to move the reduction site to an intermediate city between Paris and

329 Pisa and then to integrate into this comparison the data obtained within a $700 \mathrm{~km}$ radius around this new reduction site. Here, we chose Beaune in the Burgundy region, home to the

331 famous Hôtel-Dieu de Beaune (Figure 6). Note that one of the French data, precisely dated to 332 the mid-15th century from archival documents, has been obtained from analysis of pavement 333 tiles from the so-called King's Room in the Hospices de Beaune (Genevey et al. 2009). 2009, 2013 and this study), as together they form a very homogeneous data collection from an experimental point of view (i.e., same experimental protocol and selection criteria). Their 337 geographic distribution is shown in Figure 6 (blue and pink circles), and their intensity values 338 reduced to the latitude of Beaune are reported in Figure 7a. We observe that they are 339 remarkably consistent and complementary. The Tuscan data confirm some of the rapid 340 intensity variations previously observed only from the French dataset (Genevey et al. 2009, $3412013,2016)$. It is worth recalling that the latter dataset showed that these variations were 342 characterised throughout the past millennium by three peaks in intensity detected during the 343 12th century, the second part of the 14th century, and around AD 1600. The Tuscan data 344 allow us to constrain the intensity maximum at the transition of the 16th and 17th centuries, 345 with a peak that now appears better defined and more pronounced (Figure 7a). The new result 346 dated from the middle of the 12th century is also important because it further documents the 347 peak of intensity observed during this century, in particular the rapid decrease in intensity 348 between c. 1150 and c. 1250. 
$350 \mathrm{~km}$ radius of Beaune (Figure 6), which fulfil modern quality criteria (as defined by, for 351 example, Genevey et al. 2016). We only kept data with age uncertainties of less than 100 352 years, considering that for this recent period of European history, it is possible to access such 353 accurate dating when the aim is to recover rapid geomagnetic field intensity variations. 354 Overall, the data available are very consistent. The additional data included here (Chauvin et al. 2000; Casas et al. 2005; Donadini et al. 2008; Gómez-Paccard et al. 2012) allow, in particular, a better description of intervals characterised by a decrease in intensity - i.e., during the 10th, 15 th and 17 th centuries.

From the data selection above, we constructed a reference intensity variation curve using the method recently developed by Livermore et al. (2018). This method relies on a trans-dimensional Bayesian approach that aims to fit a series of linear segments to the data,

361 the number of which is self-determined by the data themselves. A great asset of this technique 362 is the minimum regularisation imposed on the fit to the dataset (see discussion in Livermore 363 et al., 2018). The average curve obtained, and its 95\% confidence interval, is shown in Figure $3647 \mathrm{~b}$. The results are very similar to those previously discussed by Genevey et al. (2016) and 365 Livermore et al. (2018) using different averaging techniques, which further demonstrates the 366 robustness of the three intensity peaks observed over the past millennium. Note that this result 367 is particularly interesting for the attempts to find a correlation (and possible causal link) 368 between geomagnetic field intensity peaks and cooling episodes in Western Europe as 369 documented by advances and retreats of alpine glaciers, as well as with fluctuations in the 370 C14 production rate (Gallet et al. 2005; Genevey et al. 2009, 2013). Furthermore, it is also 371 worth reminding that the three intensity peaks, now better defined thanks to the new Tuscan 372 data, are part of a set of five maxima regularly spaced since about 1500 years ago, with a 373 pseudo period of $\sim 250$ years (Genevey et al. 2016; Livermore et al. 2018). 
375 Europe is well documented by sets of data mainly acquired in northern Germany (Schnepp et al. 2009), Spain (Gómez-Paccard et al. 2006, 2008, 2012, 2016) and further east in Bulgaria (Kovacheva et al. 2014). Comparison between, on the one hand, these results and, on the other hand, the variations predicted in Paris from different global and regional field models 379 (Pavón-Carrasco et al., 2009, 2014a; Korte et al., 2009; Licht et al., 2013), has already been widely discussed in our previous publications (Genevey et al. 2009, 2013, 2016; see also in Pavón-Carrasco et al., 2014b). It should be noted that extending the area around Beaune for instance to $900 \mathrm{~km}$ or $1000 \mathrm{~km}$ would lead to a dataset almost identical to that available in a radius of $1250 \mathrm{~km}$ around Paris (Genevey et al., 2016); we recall that in this case, the data appears significantly more scattered than the dataset available in a $700-\mathrm{km}$ radius, which results in the smoothing of most of the rapid intensity variations mentioned (see Fig. 7 in Genevey et al., 2016). Redoing this comparison work would not provide new information compared to the conclusions of Genevey et al (2016) and for this reason, we chose here to perform a comparison with a new dataset obtained in Spain (Molina-Cardín et al. 2018). These authors constructed a new intensity variation curve for the Iberian Peninsula, spanning the past 3000 years, using both new data and previous results that fulfil a set of quality 391 criteria, available in a radius of $900 \mathrm{~km}$ around Madrid. For the past millennium, this data 392 selection is essentially different from the one considered around Beaune, even if some data 393 obtained in France are common to both selections (Figure 6). Let us note that the selection criteria used by Molina-Cardín et al. (2018) are slightly less restrictive than those used to select the data reported in Figure $7 b$ (Genevey et al. 2013). The criteria relative to the intensity methods are the same (Thellier method with pTRM-checks and TRM anisotropy 397 effect taken into account for artefacts recognized as more anisotropic), but they differ for the 398 dating uncertainties and data accuracy. In Molina-Cardín et al. (2018), the age uncertainties 
are required to be of less than 250 years and there is no threshold value relative to the uncertainty on the intensity mean, whereas, our selection is based on a dating accuracy of less than 100 years and an uncertainty of less than $15 \%$ on the intensity mean. Applying our selection criteria to the Spanish dataset would have comparatively resulted in the rejection of 13 data, mainly on the basis of the age uncertainties (11 of the 13 data indicated by crosses in 404 Figure 7c). Regardless of the criteria considered, the data selected around Madrid are 405 significantly more scattered than those presented in Figure 7b. A mean intensity variation curve was constructed in Figure 7c using the data selection used by Molina- Cardín et al.

407 (2018). The dispersion of the data leads to a smooth evolution showing a continuous decrease 408 between c. 1100 and c. 1850 , followed in continuity by the intensity decrease predicted by 409 gufm1 at Madrid since 1850 (Figure 7c). It should be noted that the very same evolution is 410 obtained when the Spanish data are selected according to our selection criteria. The same 411 overall trend is observed from the Beaune dataset, but thanks to a higher coherence between 412 the results, it allows us to detect the existence of faster intensity variations occurring on the 413 century timescale (Figure $7 b$ ). It therefore seems likely that a reduction of the scatter in the 414 Madrid dataset would allow the emergence of the same three intensity peaks observed in 415 France and partly in Italy. From this point of view, the data obtained in France and in Tuscany 416 indicate that the construction of a mean intensity variation curve with a resolution on a 100417 year timescale is an achievable objective, although it must be acknowledged that this is 418 clearly a difficult task.

\section{Acknowledgments}

421 The authors are indebted with Federico Andreazzoli for his great help for the selection of the 422 structures and on the field. Claudia Principe wants to remember here their two-voices speech 423 from the pulpit of the church of Marti about devil and archaeomagnetism. We are also pleased 
424 to thank Fiorella Ramacogi and the late Mario Ferretti from the Soprintendenza to 425 Monuments of Pisa, who produced us the due authorization for sampling. We are grateful to 426 two anonymous reviewers for their helpful comments on the manuscript. This research was 427 supported by the CNRS (Projet International de Collaboration Scientifique, PICS ${ }^{\circ} 3063$ ) and 428 by the Simone and Cino Del Duca Foundation of the French Academy of Science (ID 429 100009515). This is IPGP contribution no. 4093.

\section{References}

432 Aitken, M. J., Allsop, A. L., Bussell, G. D., Winter, M. B., 1988. Determination of the intensity of the Earth's magnetic field during archaeological times: Reliability of the Thellier technique. Rev. Geophys. 26, 3-12.

Alberti, A., Baldassarri, M., 2004. a cura di, Dal castello alla "terra murata". Calcinaia e il suo territorio nel Medioevo, Firenze.

Alberti, A., 2015. La forace Coccapani di Calcinaia. Recupero della Memoria e musealizzazione. In. Bruni S., ed., "Rentamer le discours. Scritti per Mauro Del Corso", 39-47.

Arrighi, S., Tanguy, J.-C., Rosi, M., 2006. Eruption of the last 2200 years at Vulcano and Vulcanello (Aeolian Islands, Italy) dated by high-accuracy archaeomagnetism. Phys. Earth Planet. Inter. 159, 225-233.

Branca, S., Condomines, M., Tanguy, J., C., 2015a. Flank eruptions of Mt Etna during the Greek-Roman and Early Medieval periods: New data from Ra-226-Th-230 dating and archaeomagnetism. J. Volcanol.Geothermal. Res., 304, 265-271, DOI: 10.1016/j.jvolgeores.2015.09.002. 
Branca, S., Coltelli, M., Groppelli, G., 2015b. Geological Map of Etna Volcano, with contributions of Carbone, E., Lentini, F., De Beni, E., Tanguy, J.-C., Wijbrans, J. R., Memorie descrittive della carta geologica d'Italia, XCVIII.

Carratori, L., Ceccarelli Lemut, M. L., Frattarelli, F., Garzella,G., Greco, G., Grifoni Cremonesi, R., Mazzanti, R., Morelli, P., Nencini, C., Pasquinucci, M., Pescaglini Monti, R., Pult Quaglia, A.M., Rau, A., Ronzani, M., Tozzi, C., 1991. Carta 1:50.000 degli elementi naturalistici e storici della pianura di Pisa e dei rilievi contermini. CSGDSA-CNR e Provincia di Pisa, SELCA. In "La Pianura di Pisa ed i rilievi contermini. La natura e la storia”, Renzo Mazzanti (a cura di), Roma, Memorie della Società Geografica Italiana, vol. L, 1994.

Casas, L., Shaw, J., Gich, M., Share, J. A., 2005. High-quality microwave archaeointensity determinations from an early $18^{\text {th }}$ century AD English brick kiln. Geophys. J. Int., 161, 653-661.

Chauvin, A., Garcia, Y., Lanos, P., Laubenheimer, F., 2000. Paleointensity of the geomagnetic field recovered on archaeomagnetic sites from France. Phys. Earth Planet. Inter., 120, 111-136.

Clemente G., 2015, Fornaci da mattoni e fornaciai a Pisa tra XV e XVI secolo attraverso le fonti documentarie, in Luongo. A., Paperini M., 2015, a cura di, Medioevo in Formazione, III. Studi storici e multidisciplinarietà, Livorno, pp. 151-157.

Clemente G. 2017, Ceramisti e produzione ceramica a Pisa tra Medioevo ed età Moderna, in 'Ricerche Storiche', XLVI/3, 2016, pp. 133-145.

Ciuti, R., 2003. Pisa Medicea. Itinerario Storico Artistico tra Cinquecento e Seicento, Pisa.

Donadini, F., Pesonen, L.J., 2007. Archaeointensity determinations from Finland, Estonia, and Italy. Geophysica, 43(1-2), 3-18. 
Donadini, F., Kovacheva, M., Kostadinova, M., Hedley, I.G., Pesonen, L.J., 2008. Palaeointensity determination on an early medieval kiln from Switzerland and the effect of cooling rate. Phys. Earth. Planet. Inter., 33, 449-457.

Evans, M.E., 1986. Paleointensity estimates from Italian kilns. J. Geomagn. Geoelect. 38, $1259-1267$.

Evans, M.E., 1991. An archaeointensity investigation of a kiln at Pompeii. J. Geomagn. Geoelect. 3843(5), 357-361.

Febbraro, M., 2006. La pieve di S. Maria Novella di Marti. Spunti interpretativi per una conoscenza dell'architettura in laterizi nel Valdarno inferiore, in Baldassarri M., Ciampoltrini G. 2006, a cura di, I Maestri dell'Argilla. L'edilizia in cotto, la produzione di laterizi e di vasellame nel Valdarno Inferiore tra Medioevo ed età Moderna, Pisa, pp. 51-64.

Gallet, Y., Genevey, A., Fluteau, F., 2005. Does Earth's magnetic field secular variation control centennial climate change?, Earth Planet. Sci. Lett., 236, 339-347.

Gallet, Y., Le Goff, M., 2006. High-temperature archaeointensity measurements from Mesopotamia. Earth Planet. Sci. Lett. 241, 159-173.

Gallet, Y., Genevey, A., Le Goff, M., Warmé, N., Gran-Aymerich, J., Lefèvre, A., 2009. On the use of archaeology in geomagnetism, and vice-versa: Recent developments in archaeomagnetism. C. R. Physique, 10 630-648.

Gasperini, M., Greco, G., Noferi, M., Tagliagamba, S., 2015. a cura di, Il Principe, la città, l'acqua. L'acquedotto mediceo di Pisa, Pisa.

Gattiglia, G., Milanese, M., 2006. Palazzo Scotto Corsini. Archaeologia e storia delle trasformazioni di un'area urbana a Pisa tra XI e XX secolo, Pisa. 
494 Genevey, A., Gallet, Y., 2002. Intensity of the geomagnetic field in western Europe over the past 2000 years: new data from ancient French pottery. J. Geophys. Res. 107 (B11), doi:10.1029/2001JB000701.

497

498

499

500

501

502

503

504

505

506

507

508

509

510

Genevey, A., Gallet, Y., Constable, C. G., Korte, M., Hulot, G., 2008. ArchaeoInt: An upgraded compilation of geomagnetic field intensity data for the past ten millennia and its application to the recovery of the past dipole moment. Geochem. Geophys. Geosyst., 9, Q04038, doi:10.1029/ 2007GC001881.

Genevey, A., Gallet, Y., Rosen, J., Le Goff, M., 2009. Evidence for rapid geomagnetic field intensity variations in Western Europe over the past 800 years from new archaeointensity French data. Earth Planet. Sci. Lett. 284, 132-143.

Genevey, A., Gallet, Y., Thébault, E., Jesset, S., Le Goff, M., 2013. Geomagnetic field intensity variations in Western Europe over the past 1100 years. Geochem. Geophys. Geosyst. 14/8, 2858-2872.

Genevey, A., Gallet, Y., Jesset, S., Thébault, E., Bouillon, J., Lefèvre, A., Le Goff, M., 2016. New archaeointensity data from French Early Medieval ceramic production (6th-10th century AD). Tracing 1500 years of geomagnetic field intensity variations in Western Europe. Phys. Earth Planet. Inter. 257, 205-219.

Gómez-Paccard, M., Chauvin, A., Lanos, P., Thiriot, J., Jiménez-Castillo, P., 2006. Archaeomagnetic study of seven contemporaneous kilns from Murcia (Spain). Phys. Earth Planet. Inter., 157, 16-32.

Gómez-Paccard, M., Chauvin, A., Lanos, P., Thiriot, J., 2008. New archaeointensity data from Spain and the geomagnetic dipole moment in western Europe over the past 2000 years. J. Geophys. Res., 113, B09103, doi:10.1029/2008JB005582. 
Gómez-Paccard, M., Chauvin, A., Lanos, P., Dufresne, P., Kovacheva, M., Hill, M. J., Beamud, E., Blain, S., Bouvier, A., Guibert, P., and Archaeological Working Team, 2012. Improving our knowledge of rapid geomagnetic field intensity changes observed in Europe between 200 and 1400 AD. Earth Planet. Sci. Lett., 355-356, 131-143.

Gómez-Paccard, M., Osete, M. L., Chauvin, A., Pavón-Carrasco, F. J., Pérez-Asensio, M., Jiménez, P., Lanos, P., 2016. New constraints on the most significant paleointensity change in Western Europe over the last two millennia. A non-dipolar origin? Earth Planet. Sci. Lett., 454, 55-64.

Hartmann, G., Genevey, A., Gallet, Y., Trindade, R., Etchevarne, C., Le Goff, M., Afonso, M., 2010. Archaeointensity in Northeast Brazil over the past five centuries. Earth Planet. Sci. Lett. 296, 340-352.

Hartmann, G., Genevey, A., Gallet, Y., Trindade, R., Le Goff, M., Najjar, R., Etchevarne, C., Afonso, M., 2011. New historical archaeointensity data from Brazil : Evidence for a large regional non-dipole field contribution over the past few centuries. Earth Planet. Sci. Lett. 306, 66-76.

Hedley, I., Wagner, G.C., 1991. A magnetic investigation of roman andpre-roman pottery, in Archaeometry '90 pp. 275-284, eds Pernicka, E. \&Wagner, G.C., Birkhäuser verlag, Basel.

Hervé, G., Fassbinder, J., Gilder, S., Metzner-Nebelsick, C., Gallet, Y., Genevey, A., Schnepp, E., Geisweid, L., Pütz, A., Reub, S., Wittenborn, F., Flontas, A., Linke, R., Riedel, G., Walter, F., Westhausen, I., 2017. Fast geomagnetic field intensity variations between 1400 and 400 BCE: new archaeointensity data from Germany. Phys. Earth Planet. Inter. 270, 143-156. 
Hill, M., Lanos, P., Chauvin, A., Vitali, D., Laubenheimer, F., 2007. An archaeomagnetic investigation of a Roman amphorae workshop in Albinia (Italy). Geophys. J. Int. 169, 471-482.

Hill, M.J., Lanos, P., Denti, M., Dufresne, P., 2008. Archaeomagnetic investigation of bricks from the VIIIth-VIIth century BC Greek-indigenous site of Incoronata (Metaponto, Italy). Phys. Chem. Earth 33, 523-533.

Jackson, A., Jonkers, A., Walker M., 2000. Four centuries of geomagnetic secular variation from historical records. Philos. Trans. R. Soc. London Ser. A 358, 957- 990.

Kapper, L., Anesin, D., Donadini, F., Angelucci, D., Cavulli, F., Pedrotti, A., Hirt, A., 2014, Linking site formation processes to magnetic properties. Rock- and archaeomagnetic analysis of the combustion levels at Riparo Gaban (Italy), J. Arch. Sci., 41, 836-855.

Kovacheva, M., Kostadinova-Avramova, M., Jordanova, N., Lanos, Ph., Boyadzhiev, Y., 2014. Extended and revised archaeomagnetic database and secular variation curves from Bulgaria for the last eight millennia. Phys. Earth Planet. Inter., 236, 79-94.

Korte, M., Donadini, F., Constable, C. G., 2009. Geomagnetic field for 0-3 ka: 2. A new series of time-varying global models. Geochem. Geophys. Geosyst., 10, Q06008, doi:10.1029/2008GC002297.

Le Goff, M., Gallet, Y., 2004. A new three-axis vibrating sample magnetometer for continuous high-temperature magnetization measurements: applications to paleo- and archaeo-intensity determinations. Earth Planet. Sci. Lett. 229, 31-43.

Licht, A., Hulot, G., Gallet, Y., Thébault, E., 2013. Ensembles of low degree archaeomagnetic field models for the past three millennia. Phys. Earth. Planet. Inter., 224, 38-67. 
Livermore, P. W., Fournier, A., Gallet, Y., 2014. Core-flow constraints on extreme archaeomagnetic intensity changes. Earth Planet. Sci. Lett., 387, 145-156, doi:10.1016/j.eps1.2013.11.020.

Livermore, P.W., Fournier, A., Gallet, Y., Bodin, T., 2018. Transdimensional inference of archaeomagnetic intensity change. Geophys. J. Int. 215, 2008-2034.

López-Sánchez, J., McIntosh, G., Osete, M.L., del Campo, A., Villalain, J.J., Pérez, L., M. Kovacheva, M., Rodriguez de la Fuente, O., Epsilon iron oxide: Origin of the high coercivity stable low Curie temperature magnetic phase found in heated archaeological materials, Geochem. Geophys. Geosyst. 18, 2646-2656.

Lowrie, W., 1990. Identification of ferromagnetic minerals in a rock by coercivity and unblocking temperatures properties. Geophys. Res. Lett., 17, 159-162.

Malfatti, J., Principe, C., Gattiglia, G., 2011. Archaeomagnetic Directional Investigation of a Metallurgical Furnace in Pisa (Italy). Journal of Cultural Heritage; vol 12, 2011, 1-10.

Molina-Cardín, A., Campuzano, S. A., Osete, M. L., Rivero-Montero, M., Pavón-Carrasco, F. J., Palencia-Ortas, A., Martín-Hernández, F., Gómez-Paccard, M., Chauvin, A., Guerrero-Suárez, S., Pérez-Fuentes, J. C., McIntosh, G., Catanzariti, G., Sastre Blanco, J. C., Larrazabal, J., Fernández Martínez, V. M., Álvarez Sanchís, J. R., RodríguezHernández, J., Martín Viso, I., Garcia i Rubert, D., 2018. Updated Iberian Archaeomagnetic Catalogue: New Full Vector Paleosecular Variation Curve for the Last Three Millennia. Geochem. Geophys. Geosyst., 19, 10, 3637-3656.

Paolillo, A., Principe, C., Bisson, M., Gianardi, R., Giordano, D., La Felice, S., 2016. Volcanology of the South-Western sector of Vesuvius, Italy. Journal of Maps, 12, 425440, DOI 10.1080/17445647.2016.1234982. 
Pavón-Carrasco, F. J., Osete, M. L., Torta, J. M., Gaya-Piqué, L. R., 2009. A regional archaeomagnetic model for Europe for the last 3000 years, SCHA.DIF.3K: Applications to archaeomagnetic dating. Geochem. Geophys. Geosyst., 10, Q03013, doi:10.1029/2008GC002244.

Pavón-Carrasco, F. J., Osete López, M. L., Torta, J. M., De Santis, A., 2014a. A geomagnetic field model for the Holocene based on archaeomagnetic and lava flow data. Earth Planet. Sci. Lett., 388, 98-109.

Pavón-Carrasco, F. J., Gómez-Paccard, M., Hervé, G., Osete López, M. L., Chauvin, A., 2014b. Intensity of the geomagnetic field in Europe for the last $3 \mathrm{ka}$ : Influence of data quality on geomagnetic field modelling. Geochem. Geophys. Geosyst., 15, 2515-2530, doi:10.1002/2014GC00531.

Principe, C., Tanguy, J.C., Arrighi, S., Paiotti, A., Le Goff, M., Zoppi, U., 2004. Chronology of Vesuvius' activity from A.D. 79 to 1631 based on archaeomagnetism of lavas and historical sources, Bull. Volcanol. 66,703-724.

Principe, C., Gogichaishvili, A., Arrighi, S., Devidze, M., Le Goff, M., La Felice, S., Paolillo, S., Giordano D., Morales, J., 2018. Archaeomagnetic dating of Copper Age furnaces at Croce di Papa village and relations on Vesuvius and Phlegraean Fields volcanic activity. Journal of Volcanology and Geothermal Energy, 349 (2018) 217-229

Quiros Castillo, J.A. 1997. La mensiocronologia dei laterizi della Toscana: problematiche e prospettive della ricerca. In: Archaeologia dell'Architettura, II, pp. 159-166.

Salnaia, N., Gallet, Y., Genevey, A., Antipov, I., 2017. New archaeointensity data from Novgorod (North-Western Russia) between c. 1100 and 1700 AD. Implications for the European intensity secular variation. Phys. Earth Planet. Inter. 269, 18-28. 
608 Schnepp, E., Lanos, P., Chauvin, A., 2009. Geomagnetic paleointensity between 1300 and

609

610

611

612

613

614

615

616

617

618

619

620

621

622

623

624

625

626

627

628

629

630

631 1750 A.D. derived from a bread oven floor sequence in Lübeck, Germany. Geochem. Geophys. Geosyst., 10, Q08003, doi:10.1029/2009GC002470.

Sodi, S., Radi, A., 1979. L'Oratorio di S. Bernardino e la sua confraternita, Pisa.

Sodi, S., Renzoni, S., 2003. La chiesa di Santo Stefano e la piazza dei Cavalieri, Pisa.

Tanguy, J.-C., Le Goff, M., Chillemi, V., Paiotti, A., Principe, C., La Delfa, S., Patanè, G, 1999. Secular variation of the geomagnetic field direction recorded in lavas from Etna and Vesuvius during the last two millennia. C.R. Acad. Sci., Series IIA, Earth and Planetary Sciences, 329, 557-564.

Tanguy, J.C., LeGoff, M., Principe, C., Arrighi, S., Chillemi, V., Paiotti, A., LaDelfa, S., Patanè, G., 2003. Archaeomagnetic dating of Mediterranean volcanics of the last 2100 years: validity and limits. Earth Planet. Sci. Lett. 211, 111-124.

Tanguy, J.-C., Condomines, M., Le Goff, M., Chillemi, V., La Delfa, S., Patanè, G., 2007. Mount Etna eruptions of the last 2,750 years: revised chronology and location through archaeomagnetic and ${ }^{226} \mathrm{Ra}-{ }^{230} \mathrm{Th}$ dating. Bull. Volcanol. 70, 55-83.

Tanguy, J., C., Condomines, M., Branca, S., La Delfa, S., Coltelli, M., 2012, New archaeomagnetic and Ra-226-Th-230 dating of recent lavas for the Geological map of Etna volcano. It. J. Geosc., 131, 2, 241-257, DOI: 10.3301/IJG.2012.01.

Tema E., Hedley, I. and Lanos, P., 2006. Archaeomagnetism in Italy: a compilation of data including new results and a preliminary Italian secular variation curve. Geophys. $J$. Int., 167, 1160-1171.

Tema, E., Goguitchaichvili, A., Camps, P., 2010. Archaeointensity determination from Italy: new data and Earth's magnetic field strength variation over the past three millennia. Geophys. J. Int.180, 596-608. 
632 Tema, E., 2011. Archaeomagnetic Research in Italy: Recent achievements and future

633

634

635

636

637

638

639

640

641

642

643

644

645

646

647

648

649

650

651

652

653

654

655 perspectives. In: The Earth's Magnetic Interior, IAGA Special Sopron Book Series, Volume 1, Chapter 15, pp. 213-233. Eds: Petrovsky, E., Herrero-Bervera, E., Harinarayana, T., Ivers, D., Springer.

Tema, E., Morales, J., Goguitchaichvili, A., Camps, P., 2013. New archaeointensity data from Italy and geomagnetic field intensity variation in the Italian Peninsula. Geophys. J. Int. $193,603-614$.

Tema, E., Camps, P., Ferrara, E., Poidras, T., 2015. Directional results and absolute archaeointensity determination by the classical Thellier and the multi-specimen DSC protocols for two kilns excavated at Osterietta, Italy, Stud. Geophys. Geod., 59, DOI: 10.1007/s11200-015-0413-0.

Tema, E., Ferrara, E., Camps, P., Conati Barbaro, C., Spatafora, S., Carvallo, C., Poidras, T., 2016. The Earth's magnetic field in Italy during the Neolithic period: New data from the Early Neolithic site of Portonovo (Marche, Italy). Earth Planet. Sci. Lett. 448, 4961.

Thellier, E., Thellier, O., 1959. Sur l'intensité du champ magnétique tesrrestre dans le passé historique et géologique. Ann. Géophys. 15, 285-376.

Vezzoli, L., Principe, C., Malfatti, J., Arrighi, S., Tanguy, J.C., Le Goff, M., 2009. Modes and times of caldera resurgence: The $<10$ ka evolution of Ischia Caldera, Italy, from archaeomagnetic dating. Journal Volcanol Geotherm Res, 186, 305-319.

\section{Figure and Table captions}

Figure 1: Examples of Tuscan baked-brick buildings sampled for this archaeointensity study. 
656 (a) 'Bocchette di Putignano'. This dike was built in 1558 as indicated on a plaque affixed to 657 the building (b), which reads 'A PARTV VIRGINIS ANNO M. D. LVIII. CALEN. 658 NOVEMBRIS' and can be translated as 'November 2nd of the 1558th year since the date 659 Mary gave birth [to Jesus]'. (c) Cistern of the Medici aqueduct linking Pisa to Asciano Pisa 660 dated from the beginning of the 17th century. The yellow cross indicates the area selected for 661 the sampling carried out using drilling. For this site, 12 cores were collected, leaving as many 662 visible holes (d), which were then filled with tinted mortar to restore the wall as much as 663 possible (e).

664

665 Figure 2: Examples of favourable (Pise04-05A) and unfavourable (Tosc04-04B) magnetic 666 behaviour for intensity determination. (a) Diagram showing the evolution of the R'(Ti) data 667 over the temperature range investigated. (b) and (c) Corresponding thermal demagnetisation 668 diagrams. Only one magnetisation component is observed in both cases. For the specimen 669 Pise04-05A, the R'(Ti) data are almost constant and their mean provides a reliable intensity 670 value. The decrease in the $\mathrm{R}^{\prime}(\mathrm{Ti})$ data over the entire temperature range observed for the 671 specimen Tosc04-04B indicates a varying proportionality between the NRM and TRM 672 fractions, thereby invalidating the possibility of recovering the ancient magnetic field 673 intensity for this brick fragment.

674

675 Figure 3: Characterisation of the magnetic mineralogy. Typical example of thermal 676 demagnetisation of three-axis IRM acquired in fields of 1.5, 0.4 and $0.2 \mathrm{~T}$. The inserts show 677 the low field susceptibility vs temperature curves for the corresponding fragments 678 (heating/cooling in black/grey).”. 
680 Figure 4: Intensity results obtained for four groups of brick fragments. Each curve in the 681 different panels represents the evolution of the R'(Ti) data for one specimen over the 682 temperature range considered for intensity determination. There are 80 determinations, 683 corresponding to as many specimens, represented here. This figure makes it possible to assess 684 the consistency of the results obtained at the fragment and group levels

685

686 Figure 5: New archaeointensity data obtained in Pisa and its neighbouring territory, and their

687

688

690

691

692

694

695

696

697 Figure 7: Archaeointensity variations in Western Europe over the past millennium as inferred 698 from different data selections (a) New Tuscan data, together with other results previously 699 acquired in France and Belgium (Genevey and Gallet 2002; Genevey et al. 2009, 2013) and 700 from direct measurements (http://www.bcmt.fr/). (b) Intensity data fulfilling quality criteria 701 and available within $700 \mathrm{~km}$ around Beaune, and mean geomagnetic field intensity variation 702 curve, and its $95 \%$ confidence envelope, computed from this dataset using the AH-RJMCMC 703 algorithm developed by Livermore et al. (2018). The computational parameters are as 704

comparison with the other archaeointensity results available in Italy for the past millennium, the direct measurements and the intensity values expected in Pisa from the gufm1 model (Jackson et al. 2000) from 1850 onwards. All data were reduced to the latitude of Pisa.

Figure 6: Geographical distribution of the Italian archaeointensity data (pink circles, the new Tuscan data; purple squares, previously acquired data), the dataset previously acquired in France and Belgium (blue points; Genevey et al. 2009, 2013) and the other data selected (green squares) within $700 \mathrm{~km}$ around Beaune (purple circle) and within $900 \mathrm{~km}$ around Madrid (yellow circle; Molina-Cardín et al. 2018). 
length of 50 million samples and intensity priors of $30 \mu \mathrm{T}$ for the minimum and $100 \mu \mathrm{T}$ for

706 the maximum (see details in Livermore et al., 2018). Following Genevey et al. (2008), the 707 datum obtained by Casas et al. (2005) marked by '*' was decreased by $5 \%$ to account for the 708 cooling-rate effect, which was not evaluated in this study. (c) Intensity data selected by 709 Molina-Cardín et al. (2018) for a region of $900 \mathrm{~km}$ around Madrid and the corresponding 710 mean intensity variation curve computed using the same method as in (b) and with the same 711 computational parameters except for the intensity priors set at $25 \mu \mathrm{T}$ for the minimum and 95 $712 \mu \mathrm{T}$ for the maximum. Note that the time-order relationship existing for two datasets was taken 713 into account in these estimates. The symbol " $x$ " indicates the thirteen data that would not have 714 been retained if the same selection criteria as in Figure $7 \mathrm{~b}$ had been chosen. The intensity 715 values expected in Madrid since 1850 from the gufm1 model (Jackson et al. 2000) are also 716 exhibited.

Table 1: New mean archaeointensity values obtained from the fourteen Tuscan groups of architectural brick fragments analysed in the present study. 'location' indicates the city where 720 the brick fragments were sampled. Note, however, that the study carried out on the composition of the bricks suggests the same production area around Calcinaia $\left(43.68^{\circ} \mathrm{N}\right.$; $\left.10.61^{\circ} \mathrm{E}\right)$. '\# Group' indicates the archaeomagnetic identification number of each group; 'N Frag. (n Spec)' gives, respectively, the number of fragments and specimens retained to estimate a mean; ' $\mathrm{F} \pm \sigma \mathrm{F}(\mu \mathrm{T})$ ' corresponds to the mean value obtained at the sampling site with its standard deviation in $\mu \mathrm{T}$. Its reduction at the latitude of Beaune $\left(47.02^{\circ} \mathrm{N}\right)$ is given in $726 \mu \mathrm{T}$ in the last column.

Table 2: Sequence of the five series of measurements involved in the Triaxe intensity protocol. The measurements are carried out every $5^{\circ} \mathrm{C}$ (Le Goff and Gallet, 2004). 
731 Supplementary Table 1: Summary of the selection criteria used to retain the intensity results 732 at the specimen, fragment and group levels.

733

734 Supplementary Table 2: Intensity results obtained at the specimen level and mean values 735 obtained at the fragment level. 'Tmin-Tmax': Interval of temperature involved for the 736 intensity computation. 'Flab': Intensity of the laboratory field in $\mu \mathrm{T}$. 'NRM T1 (T1')'

737 column: Percentage of magnetisation fraction with unblocking temperatures larger than T1 (or 738 T1'). 'Slope R': Slope of the straight line computed from the R'(Ti) data between Tmin and 739 Tmax. 'F Triaxe': Intensity values obtained at the specimen level in $\mu \mathrm{T}$. 'F Triaxe mean value 740 per fragment $\pm \sigma \mathrm{F}^{\prime}$ : Mean intensity value obtained at the fragment level with its standard 741 error when computed from 2 values or its standard deviation when computed from 3 values. 742 *: (n1/n2/n3) indicates successively the number of fragments collected, the number of 743 fragments whose magnetization was strong enough relative to the Triaxe sensitivity and the 744 number of fragments retained to estimate a mean value at the group level. 
a)

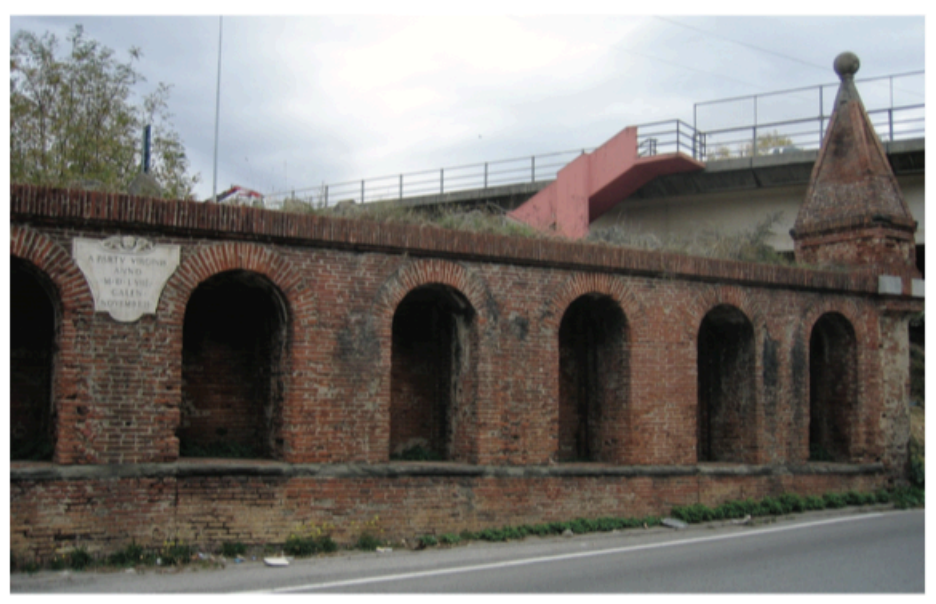

b)

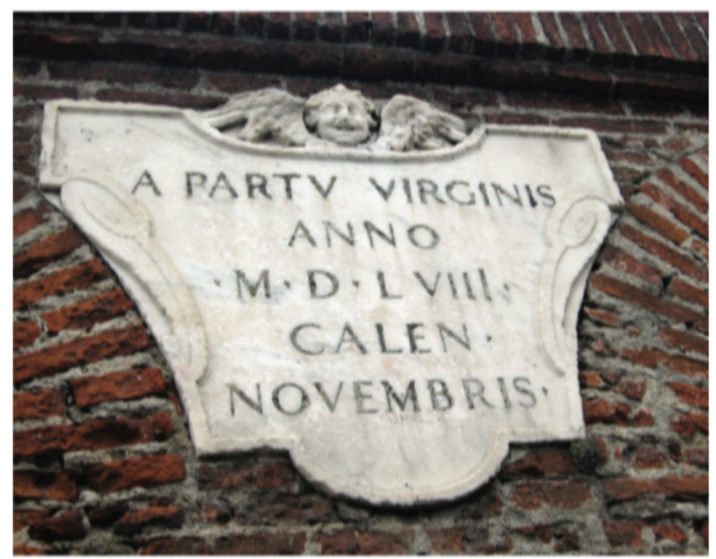

c)

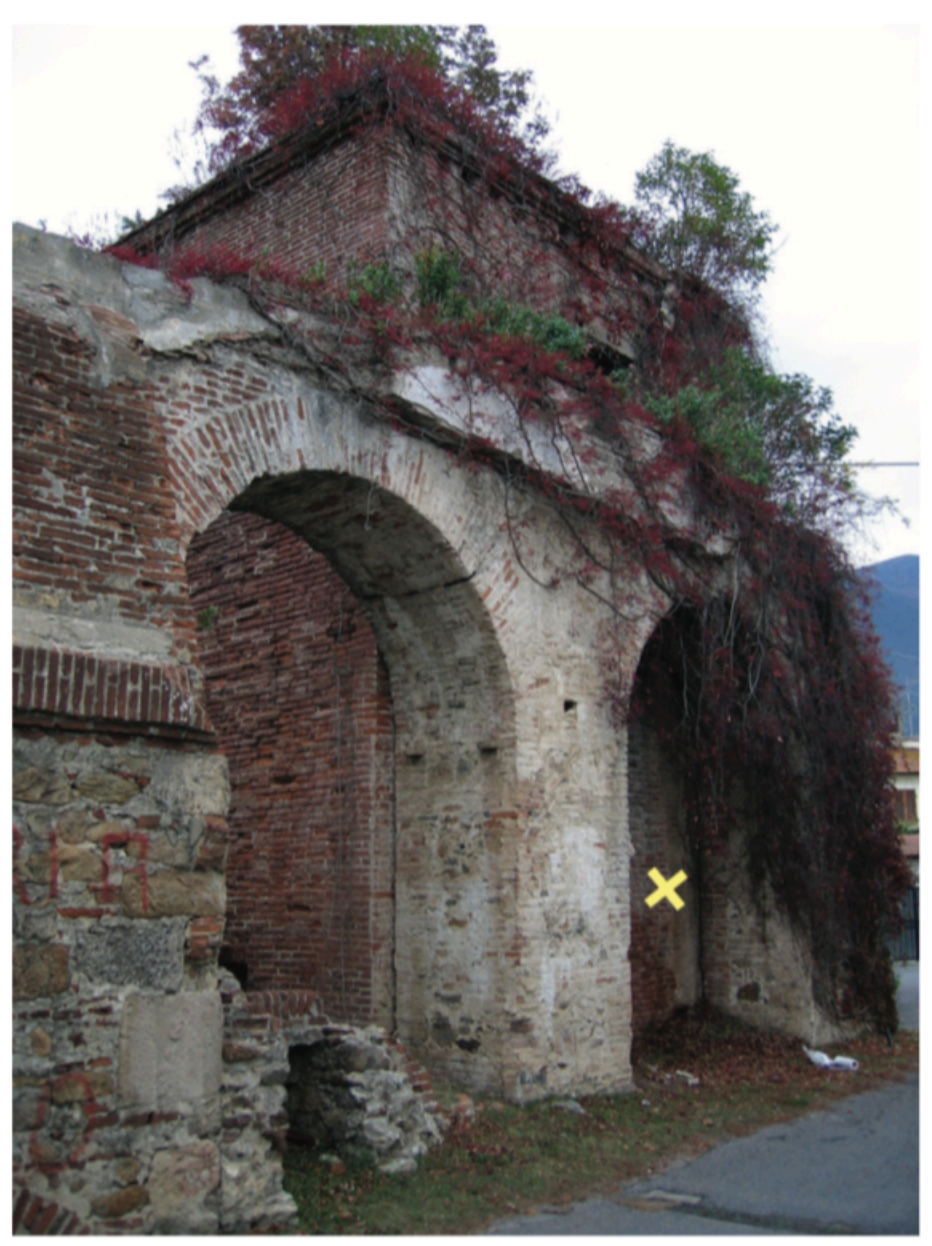

d)

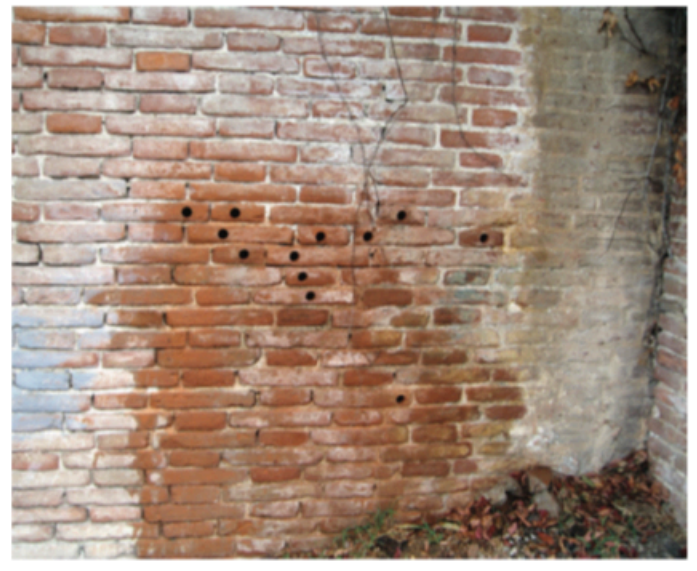

e)

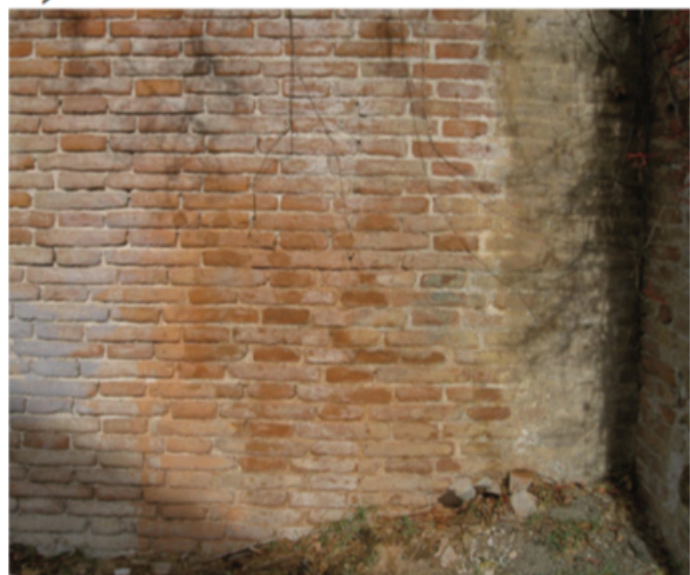

Figure 1. 
b)

a)

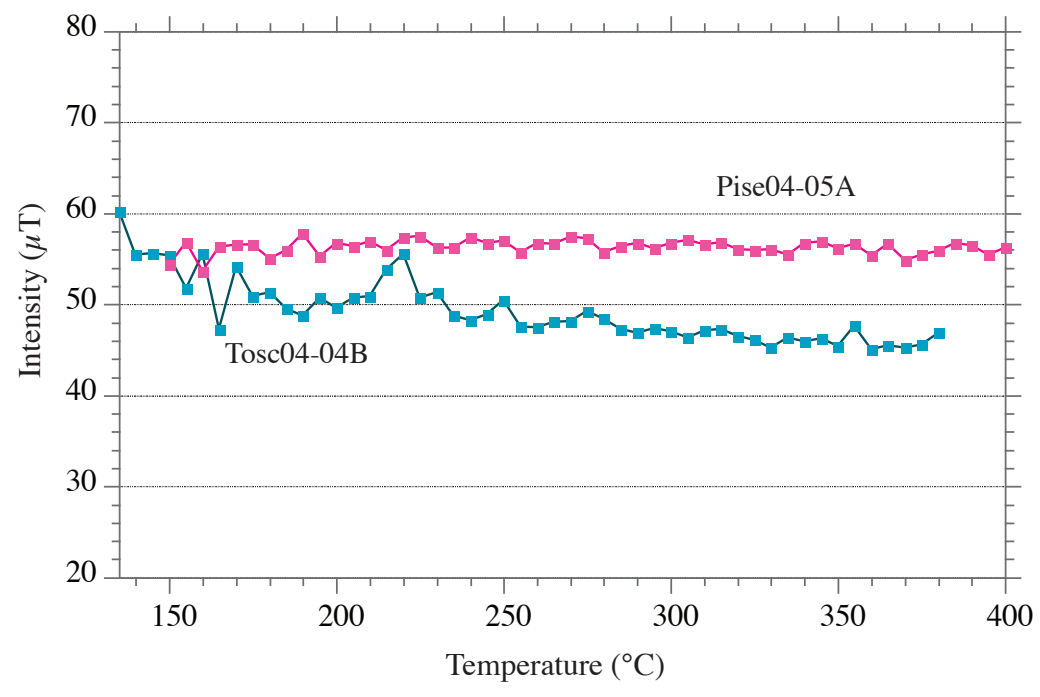

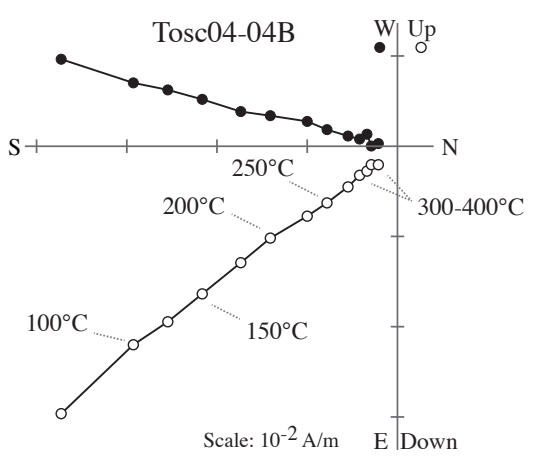

c)

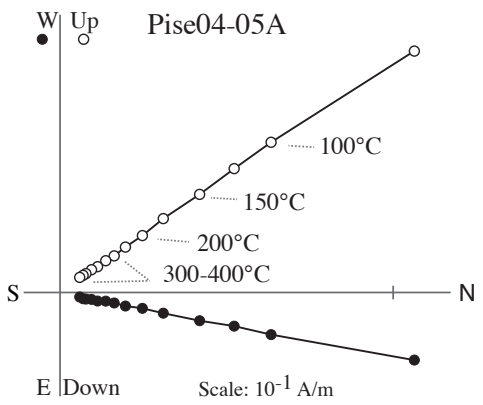

Figure 2. 
Pise02

\section{Tosc 03}

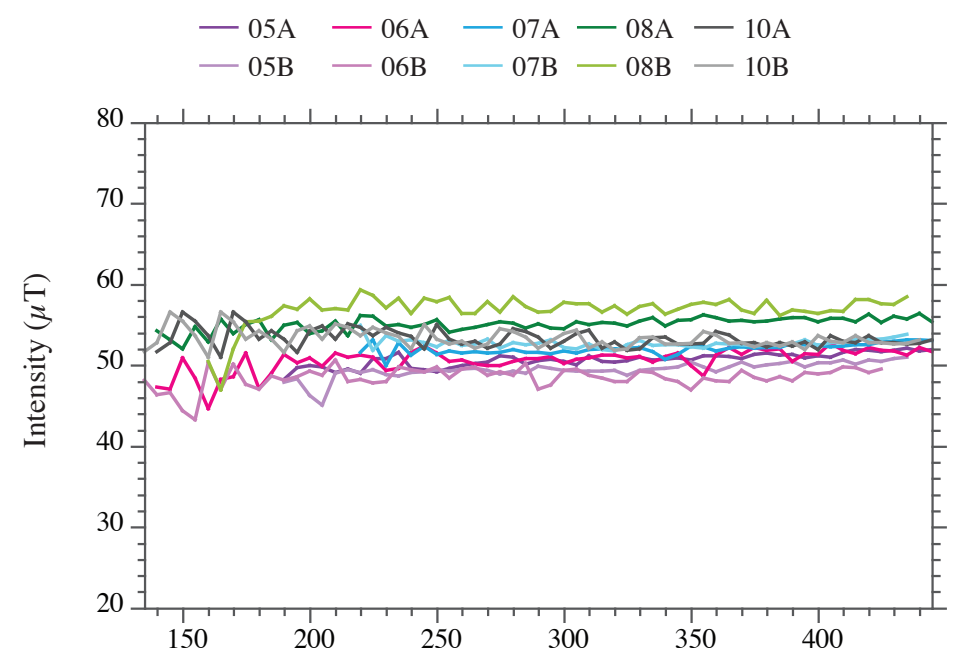

\section{Pise06}

$$
\begin{array}{rrrrr}
-01 \mathrm{~A}-02 \mathrm{~A} & -03 \mathrm{~B}-04 \mathrm{~A}-05 \mathrm{~A}-07 \mathrm{~A} \\
-01 \mathrm{~B}-02 \mathrm{~B} & -03 \mathrm{~B}-04 \mathrm{~B}-05 \mathrm{~B}-07 \mathrm{~B} \\
-08 \mathrm{~A}-09 \mathrm{~A}-10 \mathrm{~A}-11 \mathrm{~A}-12 \mathrm{~B}-13 \mathrm{~A} \\
-08 \mathrm{~B}-09 \mathrm{~B}-10 \mathrm{~B}-11 \mathrm{~B}-12 \mathrm{D}-13 \mathrm{~B}
\end{array}
$$

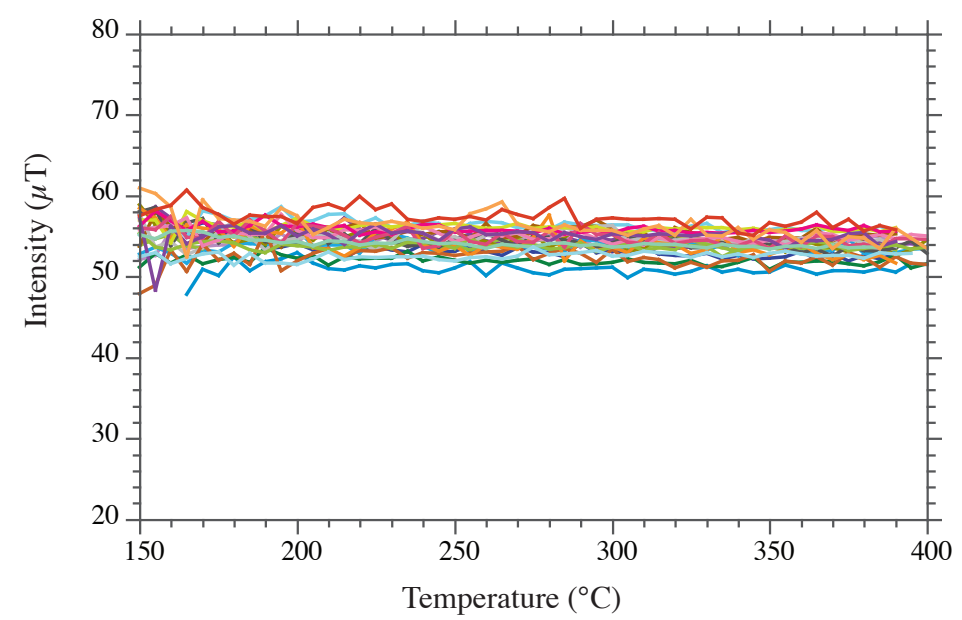

$$
\begin{array}{r}
-01 \mathrm{~A}-02 \mathrm{~A}-03 \mathrm{C}-04 \mathrm{~B}-05 \mathrm{~A}-06 \mathrm{~A} \\
-01 \mathrm{~B}-02 \mathrm{~B}-03 \mathrm{D}-04 \mathrm{~B}-05 \mathrm{~B}-06 \mathrm{~B} \\
-07 \mathrm{~A}-08 \mathrm{~A}-09 \mathrm{~B}-10 \mathrm{~A}-11 \mathrm{~A} \\
-07 \mathrm{~B}-08 \mathrm{~B}-09 \mathrm{C}-10 \mathrm{~B}-11 \mathrm{~B}
\end{array}
$$

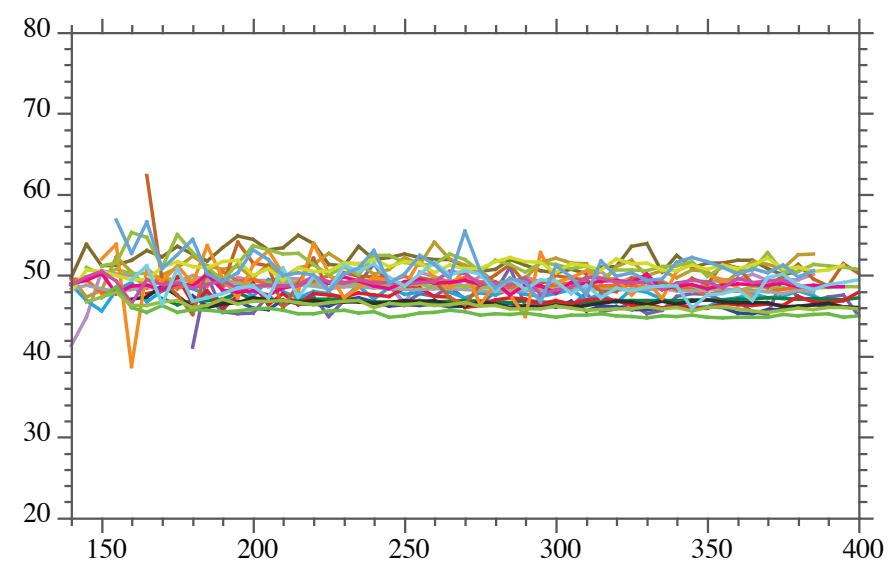

\section{Pise07}

$$
\begin{array}{rrr}
-01 \mathrm{~A}-02 \mathrm{~A} & -03 \mathrm{~A}-04 \mathrm{~A}-05 \mathrm{~A}-06 \mathrm{~A} \\
-01 \mathrm{~B}-02 \mathrm{~B}-03 \mathrm{~B}-04 \mathrm{~B}-05 \mathrm{~B}-06 \mathrm{~B} \\
-07 \mathrm{~A}-08 \mathrm{~A}-09 \mathrm{~A}-10 \mathrm{~A}-11 \mathrm{~A}-12 \mathrm{~A} \\
-07 \mathrm{~B}-08 \mathrm{~B}-09 \mathrm{~B}-10 \mathrm{~B}-11 \mathrm{~B}-12 \mathrm{~B}
\end{array}
$$

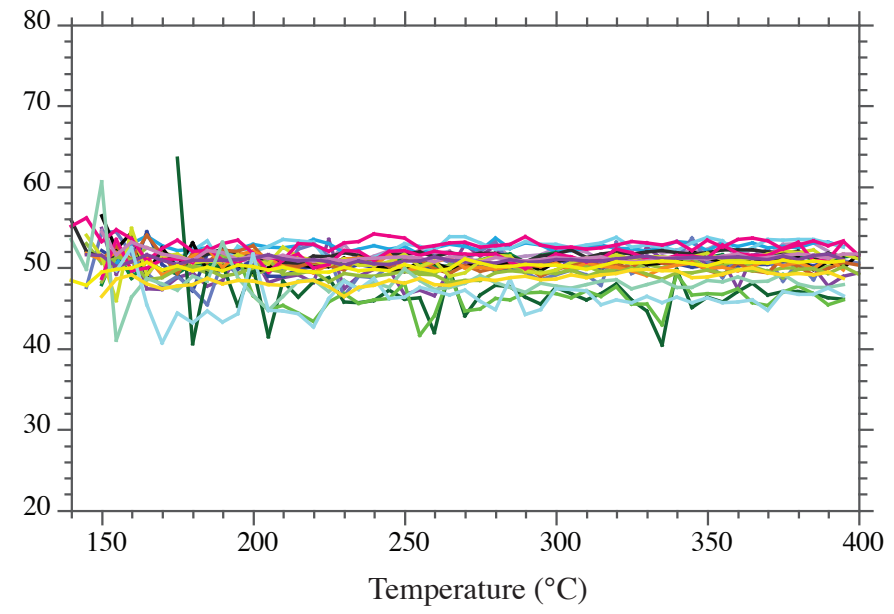

Figure 4. 
a) TOSC03-06

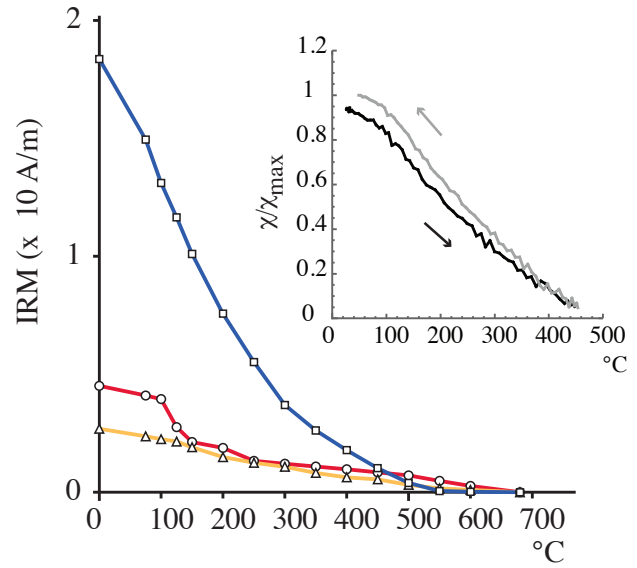

d) PISE08-06

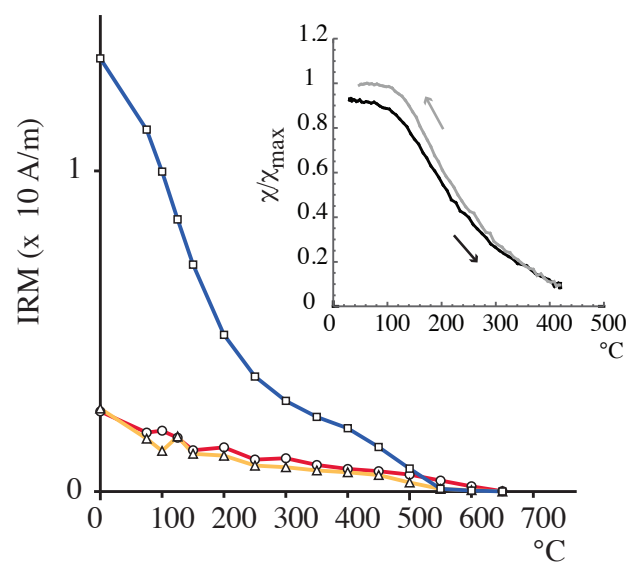

b) PISE09-94

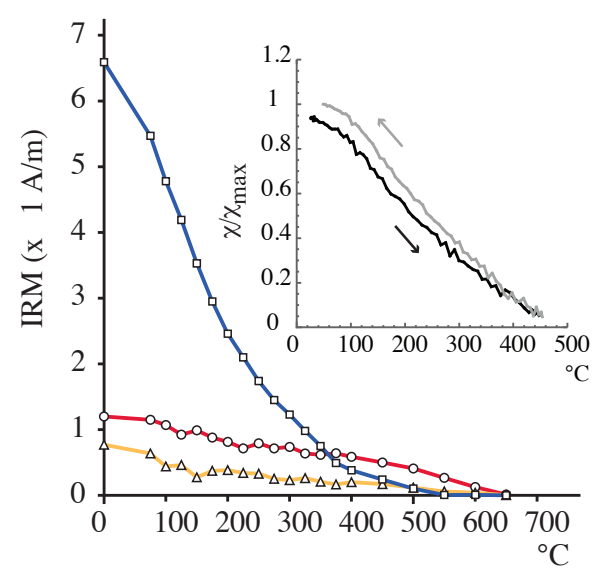

e) PISE07-04

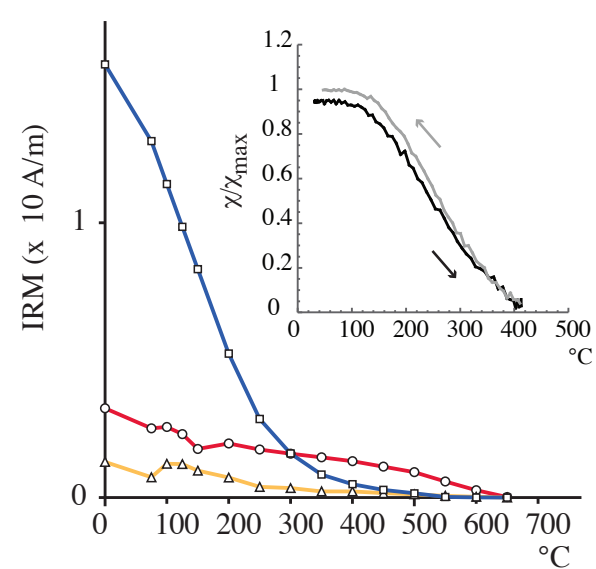

c) PISE01-08

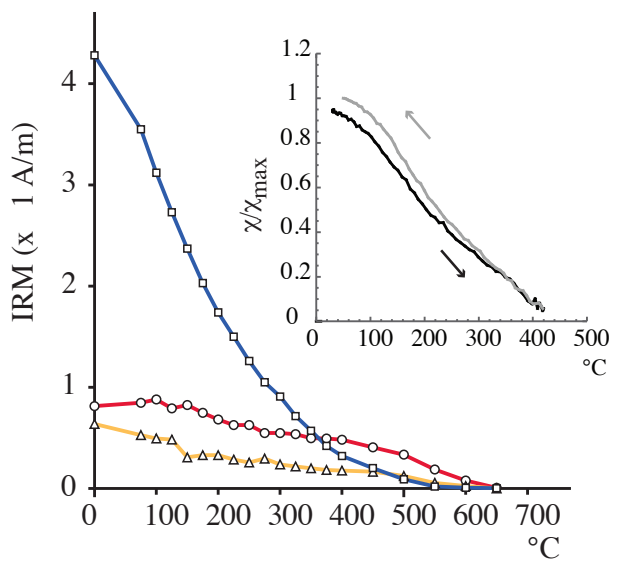

f)

PISE04-04

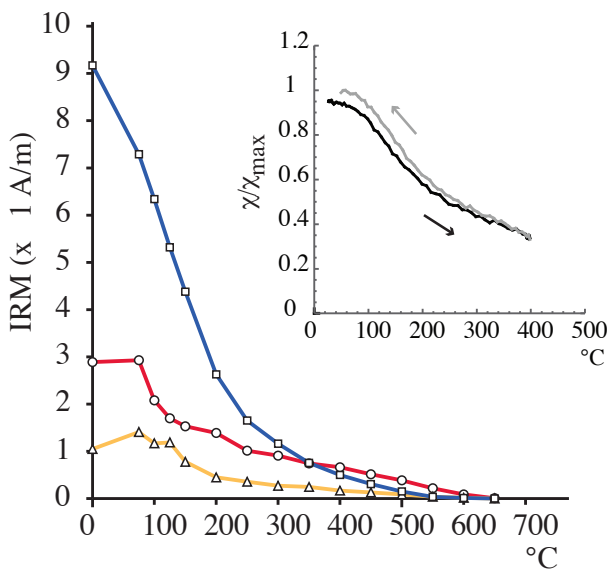

Figure 3. 


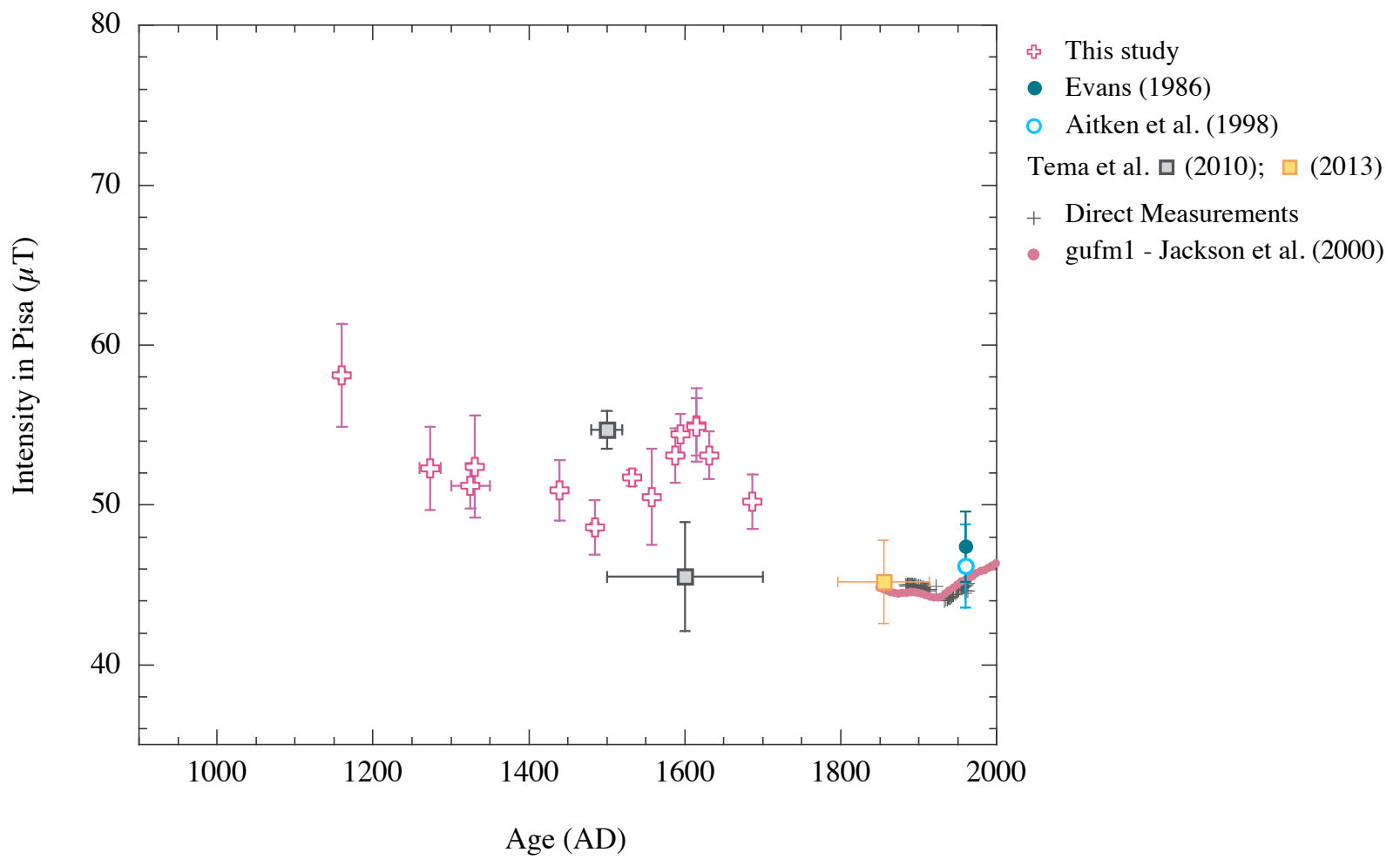

Figure 5. 


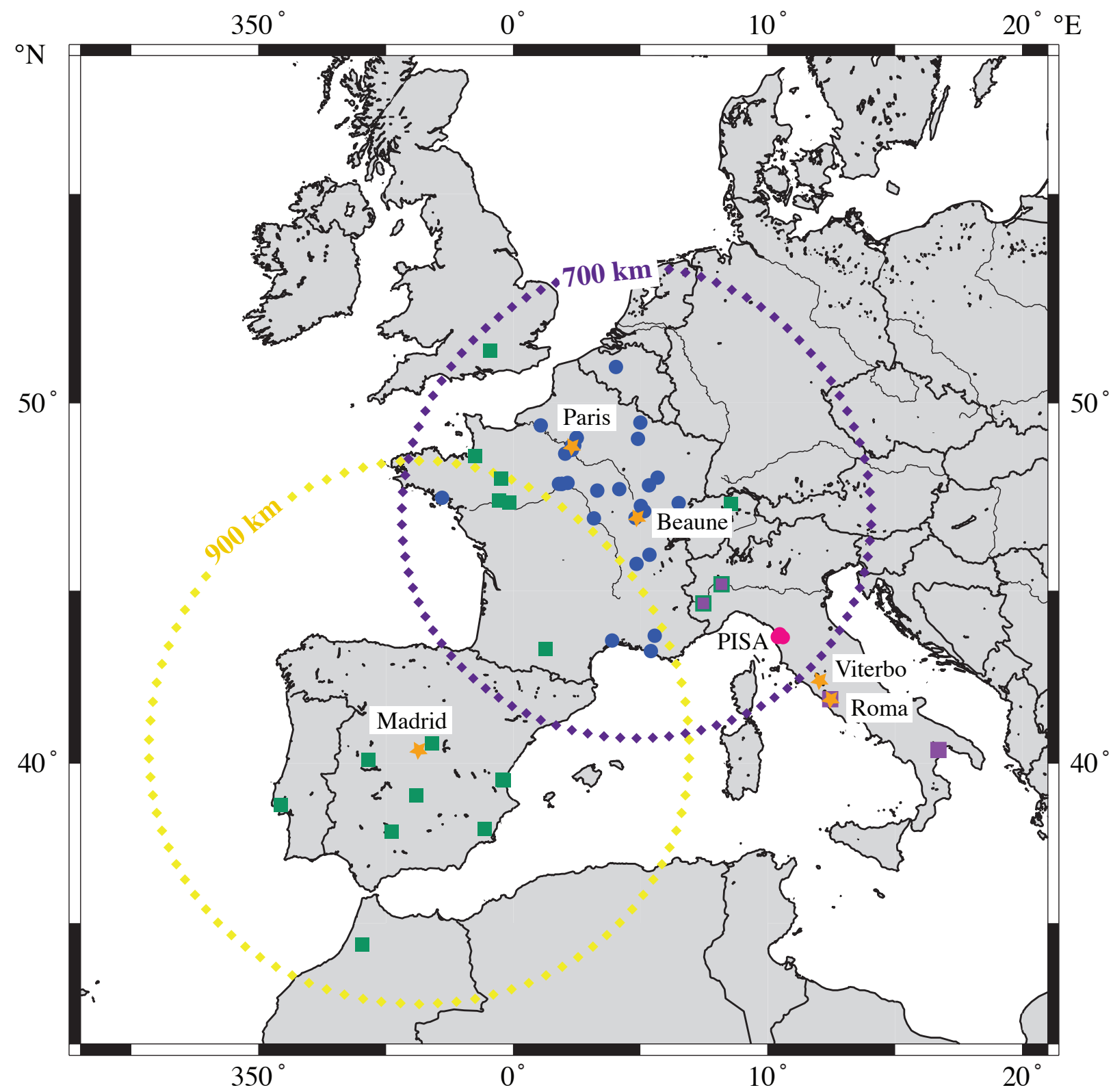

Figure 6. 
a)

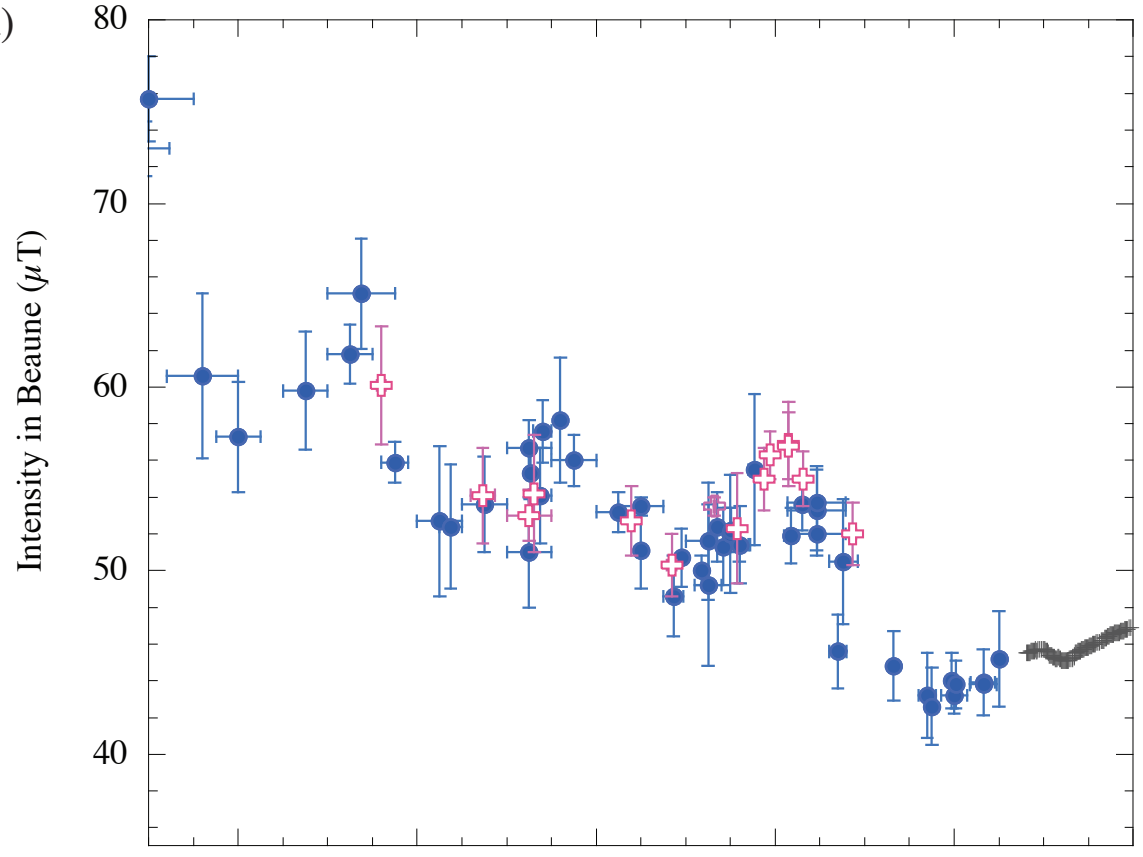

b)

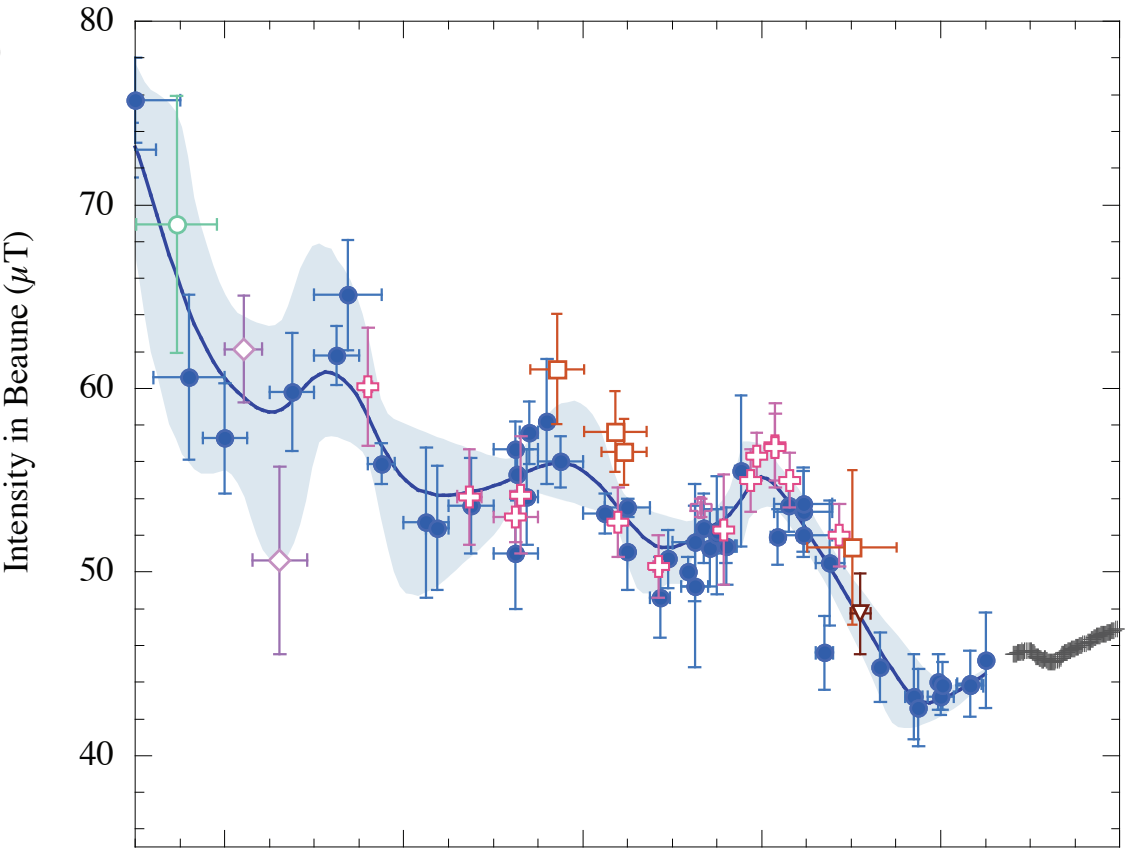

c)

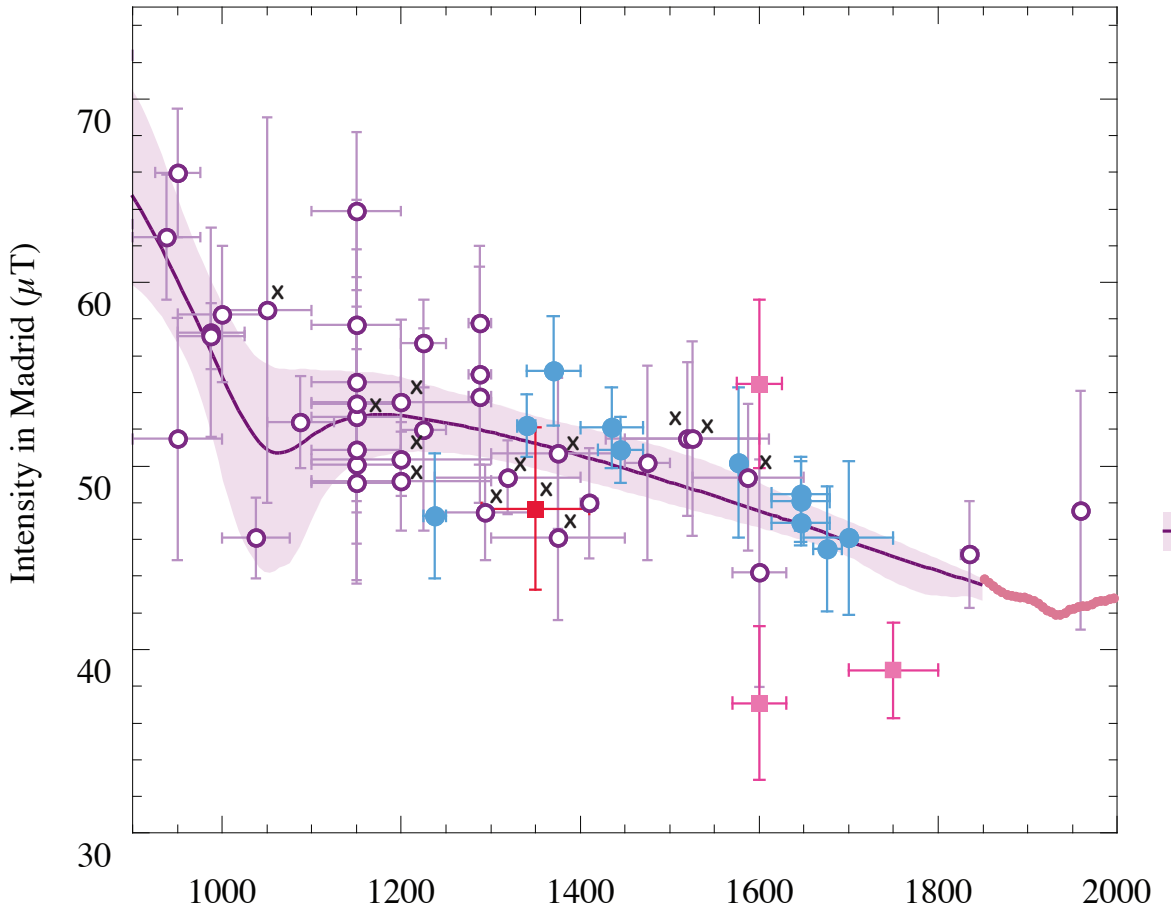

Age (AD)
5 This study

- $\quad$ Genevey and Gallet (2002)

Genevey et al. (2009;2013)

$+\quad$ Direct Measurements

$\square \quad$ Chauvin et al. (2000)

v Casas et al. (2005)*

○ Gómez-Paccard et al. (2012)

$\diamond \quad$ Donadini et al. (2008)

$700 \mathrm{~km}$ Beaune data selection

Average intensity curve and its $95 \%$ enveloppe computed using AH-RJMCMC algorithm $\circ \quad$ Spain

- Portugal

- Morocco

- France

$900 \mathrm{~km}$ Madrid data selection (Molina-Cardín et al. 2018) Average intensity curve and its $95 \%$ enveloppe computed using AH-RJMCMC algorithm

gufm1 - Jackson et al. (2000)

Figure 7. 


\begin{tabular}{|c|c|c|c|c|c|c|}
\hline Location & \# Group & Age (A.D.) & Sampled baked-brick buildings & N Frag. (n Spec.) & $\mathrm{F} \pm \sigma \mathrm{F}(\mu \mathrm{T})$ & $\begin{array}{c}\text { at Beaune }(\mu \mathrm{T}) \\
\left(47.02^{\circ} \mathrm{N} ; 4.84^{\circ} \mathrm{E}\right)\end{array}$ \\
\hline Pisa & Pise12 & $1155-1165$ & Medieval walls - Scotto Garden & $\mathrm{N}=10(\mathrm{n}=29)$ & $58.1 \pm 3.2$ & 60.2 \\
\hline \multirow[t]{8}{*}{$\left(43.71^{\circ} \mathrm{N} ; 10.40^{\circ} \mathrm{E}\right)$} & Pise11 & $1300-1350$ & Medieval walls - Second phase - Scotto Garden & $\mathrm{N}=4(\mathrm{n}=12)$ & $51.2 \pm 1.4$ & 53.0 \\
\hline & Pise10 & 1440 & New citadel - Santa Barbara tower & $\mathrm{N}=15(\mathrm{n}=30)$ & $50.9 \pm 1.9$ & 52.7 \\
\hline & Pise02 & $1479-1490$ & Oratory of San Bernardino & $\mathrm{N}=11(\mathrm{n}=22)$ & $48.6 \pm 1.7$ & 50.3 \\
\hline & Pise09 & $1531-1533$ & New Citadel - Sangallo bastion & $\mathrm{N}=5(\mathrm{n}=15)$ & $51.7 \pm 0.5$ & 53.5 \\
\hline & Pise01 & 1558 & Bocchette di Putignano & $N=3(n=9)$ & $50.5 \pm 3.0$ & 52.3 \\
\hline & Pise08 & 1588 & Medici shipyard (Arsenal) & $\mathrm{N}=6(\mathrm{n}=12)$ & $53.1 \pm 1.7$ & 55.0 \\
\hline & Pise06 & 1595 & Medici Aqueduct - Arch & $\mathrm{N}=12(\mathrm{n}=24)$ & $54.4 \pm 1.3$ & 56.3 \\
\hline & Pise07 & $1683-1691$ & Santo Stefano dei Cavalieri church - Extension of the church & $\mathrm{N}=12(\mathrm{n}=24)$ & $50.2 \pm 1.7$ & 52.0 \\
\hline \multirow{3}{*}{$\begin{array}{l}\text { Asciano Pisano } \\
\left(43.75^{\circ} \mathrm{N} ; 10.47^{\circ} \mathrm{E}\right)\end{array}$} & Pise03 & $1613-1617$ & Medici Aqueduct - Cistern & $\mathrm{N}=10(\mathrm{n}=20)$ & $55.0 \pm 1.8$ & 56.9 \\
\hline & Pise04 & $1613-1617$ & Medici Aqueduct - Pillar & $N=9(n=22)$ & $54.9 \pm 2.3$ & 56.8 \\
\hline & Pise05 & 1632 & Medici Aqueduct - Pillar & $\mathrm{N}=13(\mathrm{n}=26)$ & $53.1 \pm 1.6$ & 55.0 \\
\hline $\begin{array}{l}\text { Calcinaia } \\
\left(43.68^{\circ} \mathrm{N} ; 10.61^{\circ} \mathrm{E}\right)\end{array}$ & $\operatorname{Tos} 03$ & $1260-1287$ & Del Castello tower & $\mathrm{N}=5(\mathrm{n}=10)$ & $52.3 \pm 2.6$ & 54.1 \\
\hline $\begin{array}{l}\text { Marti } \\
\left(43.65^{\circ} \mathrm{N} ; 10.74^{\circ} \mathrm{E}\right)\end{array}$ & Tosc04 & 1331 & Santa Maria Novella church & $\mathrm{N}=10(\mathrm{n}=21)$ & $52.4 \pm 3.2$ & 54.3 \\
\hline
\end{tabular}

Table 1. 
Step

\begin{tabular}{|l|l|l|l|l|l|}
\hline$\# 1$ & Heating & from T1 & to T2 & in zero field & $=>$ Demagnetization of the NRM \\
\hline$\# 2$ & Cooling & from T2 & to T1 & in zero field & \\
\hline$\# 3$ & Heating & from T1 & to T2 & in zero field & $=>$ Control of the thermal variation on the magnetization fraction remaining unblocked at T2 \\
\hline$\# 4$ & Cooling & from T2 & to T1 & in field & => Acquisition of a laboratory TRM parallel to the NRM \\
\hline$\# 5$ & Heating & from T1 & to T2 & in zero field & $=>$ Demagnetization of the laboratory TRM \\
\hline
\end{tabular}

Table 2. 


\begin{tabular}{|l|l|l|}
\hline \multirow{4}{*}{ - Specimen level } & $\bullet$ Thermal demagnetization & $=>$ Well defined primary component isolated between Tmin $\geq \mathrm{T} 1$ and Tmax $=\mathrm{T} 2$ \\
\cline { 2 - 3 } & \multirow{3}{*}{-Intensity determination } & $=>$ Performed on the temperature range [Tmin-Tmax], where the primary component is isolated \\
\cline { 3 - 3 } & $=>$ Percentage of magnetization fraction with unblocking temperatures larger than Tmin $\geq 50 \%$ \\
\cline { 2 - 3 } & $=>$ Slope of the straight line computed between the $\mathrm{R}^{\prime}$ values at Tmin and Tmax $\leq 10 \%$ \\
& This tests the constancy of the $\mathrm{R}$ '(Ti) ratios on the [Tmin-Tmax] temperature range considered \\
\hline
\end{tabular}

- Fragment level

$=>$ At least $\mathrm{n}$ specimens $\geq 2$

$\Rightarrow$ Standart error (or standard deviation when $n \geq 3$ ) around the mean $\leq 5 \%$

- Site level

$\Rightarrow$ At least $\mathrm{N}$ fragments $\geq 3$

$\Rightarrow$ Standart deviation around the mean $\leq 5 \mu \mathrm{T}$ and $\leq 10 \%$ 


\begin{tabular}{|c|c|c|c|c|c|c|c|}
\hline \multirow[t]{2}{*}{$\overline{\text { Fragment }}$} & \multirow[t]{2}{*}{ Specimen } & \multirow{2}{*}{$\begin{array}{c}\text { Tmin-Tmax } \\
\left({ }^{\circ} \mathrm{C}\right) \\
\end{array}$} & \multirow{2}{*}{$\begin{array}{l}\text { F Lab } \\
(\mu \mathrm{T}) \\
\end{array}$} & \multirow{2}{*}{$\begin{array}{c}\text { NRM T1 } \\
\left(\mathrm{T} 1{ }^{\prime}\right) \\
\\
(\%) \\
\end{array}$} & \multirow{2}{*}{$\begin{array}{c}\text { Slope R' } \\
(\%) \\
\end{array}$} & \multirow{2}{*}{$\begin{array}{c}\text { F Triaxe } \\
(\mu \mathrm{T}) \\
\end{array}$} & \multirow{2}{*}{$\begin{array}{c}\mathrm{F} \text { Triaxe mean } \\
\text { value per } \\
\text { fragment } \pm \sigma \mathrm{F} \\
(\mu \mathrm{T})\end{array}$} \\
\hline & & & & & & & \\
\hline \multicolumn{8}{|c|}{ Pise12, Pisa, Medieval walls, [1155-1165] AD, (12/11/10)* } \\
\hline \multirow[t]{3}{*}{ Pise 12-02 } & Pise $12-02 \mathrm{~A}$ & $165-390$ & 50 & 79 & 4 & 57.3 & $58.6 \pm 1.2$ \\
\hline & Pise12-02C & $160-395$ & 55 & 82 & -2 & 59.3 & \\
\hline & Pise12-02D & $155-395$ & 55 & 84 & -2 & 59.3 & \\
\hline \multirow{3}{*}{ Pise 12-03 } & Pise 12-03A & $170-370$ & 50 & 79 & -3 & 60.0 & $61.3 \pm 1.8$ \\
\hline & Pise12-03B & $165-405$ & 55 & 80 & -6 & 60.6 & \\
\hline & Pise12-03C & $170-400$ & 60 & 78 & 0 & 63.3 & \\
\hline \multirow[t]{3}{*}{ Pise 12-04 } & Pise 12-04A & $155-390$ & 50 & 80 & -3 & 62.0 & $61.8 \pm 0.5$ \\
\hline & Pise 12-04B & $155-395$ & 55 & 77 & 0 & 61.2 & \\
\hline & Pise12-04D & $140-395$ & 55 & 84 & -3 & 62.2 & \\
\hline \multirow[t]{3}{*}{ Pise12-05 } & Pise 12-05A & $150-390$ & 50 & 71 & -3 & 59.0 & $60.3 \pm 1.4$ \\
\hline & Pise 12-05B & $150-390$ & 55 & 71 & -2 & 61.8 & \\
\hline & Pise 12-05C & $140-395$ & 55 & 81 & -2 & 60.1 & \\
\hline \multirow[t]{2}{*}{ Pise 12-06 } & Pise 12-06A & $150-390$ & 50 & 72 & 1 & 52.2 & $52.7 \pm 0.5$ \\
\hline & Pise12-06E & $155-395$ & 55 & 76 & -6 & 53.2 & \\
\hline \multirow{3}{*}{ Pise 12-07 } & Pise 12-07A & $150-385$ & 50 & 81 & -3 & 57.6 & $58.2 \pm 0.5$ \\
\hline & Pise 12-07B & $150-395$ & 55 & 84 & -3 & 58.5 & \\
\hline & Pise 12-07C & $150-395$ & 60 & 86 & -2 & 58.5 & \\
\hline \multirow[t]{3}{*}{ Pise 12-09 } & Pise 12-09A & $170-385$ & 50 & 70 & -1 & 59.5 & $59.5 \pm 0.8$ \\
\hline & Pise12-09B & $145-360$ & 55 & 62 & 1 & 58.7 & \\
\hline & Pise 12-09C & $140-395$ & 55 & 79 & -1 & 60.3 & \\
\hline \multirow[t]{3}{*}{ Pise 12-10 } & Pise12-10A & $150-385$ & 50 & 74 & -2 & 59.3 & $59.5 \pm 1.4$ \\
\hline & Pise12-10C & $150-395$ & 55 & 77 & -1 & 60.9 & \\
\hline & Pise12-10E & $150-395$ & 55 & 74 & 4 & 58.2 & \\
\hline Pise 12-11 & Pise12-11A & $150-400$ & 50 & 67 & -5 & 57.3 & $55.9 \pm 1.2$ \\
\hline & Pise12-11C & $140-395$ & 55 & 71 & 0 & 55.0 & \\
\hline & Pise12-11D & $140-395$ & 55 & 71 & -2 & 55.5 & \\
\hline Pise 12-12 & Pise 12-12A & $150-390$ & 50 & 87 & -1 & 52.2 & $53.1 \pm 1.0$ \\
\hline & Pise12-12B & $150-375$ & 55 & 89 & -2 & 52.9 & \\
\hline & Pise 12-12C & $150-390$ & 55 & 87 & -1 & 54.2 & \\
\hline Pise11, Pis & Medieval wa & ls, [1300-13 & AD, $(1$ & & & & \\
\hline Pise11-01 & Pise11-01A & $150-400$ & 50 & 75 & 1 & 50.7 & $50.9 \pm 0.2$ \\
\hline & Pise11-01C & $155-390$ & 50 & 66 & -4 & 50.9 & \\
\hline & Pise11-01D & $160-395$ & 50 & 63 & -4 & 51.1 & \\
\hline Pise11-02 & Pise11-02A & $135-390$ & 50 & 77 & -5 & 52.5 & $53.0 \pm 1.0$ \\
\hline & Pise11-02B & $140-385$ & 50 & 75 & -9 & 52.4 & \\
\hline & Pise11-02D & $135-390$ & 50 & 74 & -4 & 54.2 & \\
\hline Pise11-06 & Pise11-06A & $165-390$ & 50 & 70 & -3 & 48.7 & $49.6 \pm 1.0$ \\
\hline & Pise11-06B & $135-390$ & 50 & 75 & -1 & 50.6 & \\
\hline & Pise11-06C & $150-390$ & 50 & 74 & -4 & 49.5 & \\
\hline Pise11-11 & Pise11-11A & $150-390$ & 50 & 73 & 2 & 51.7 & $51.4 \pm 1.5$ \\
\hline & Pise 11-11B & $150-400$ & 50 & 83 & 2 & 49.8 & \\
\hline & Pise11-11C & $155-390$ & 50 & 74 & -6 & 52.8 & \\
\hline Pise10, Pis & New citadel & Santa Barl & Towe & $40 \mathrm{AD},(16$ & $/ 15)^{*}$ & & \\
\hline Pise 10-01 & Pise $10-01 \mathrm{~A}$ & $150-400$ & 50 & 76 & 1 & 51.9 & $52.7 \pm 0.8$ \\
\hline & Pise10-01B & $150-400$ & 50 & 78 & -4 & 53.5 & \\
\hline Pise 10-02 & Pise 10-02A & $170-400$ & 50 & 74 & -9 & 50.5 & $50.1 \pm 0.4$ \\
\hline & Pise 10-02B & $170-385$ & 50 & 76 & -2 & 49.7 & \\
\hline Pise 10-03 & Pise 10-03A & $150-400$ & 50 & 75 & 2 & 51.3 & $51.8 \pm 0.5$ \\
\hline & Pise 10-03B & $150-400$ & 50 & 74 & -1 & 52.3 & \\
\hline Pise 10-05 & Pise 10-05A & $150-400$ & 50 & 77 & -4 & 52.7 & $53.1 \pm 0.4$ \\
\hline & Pise 10-05B & $150-390$ & 50 & 78 & -5 & 53.5 & \\
\hline Pise 10-06 & Pise 10-06A & $165-400$ & 50 & 76 & -6 & 51.5 & $51.8 \pm 0.3$ \\
\hline & Pise 10-06B & $165-390$ & 50 & 76 & -4 & 52.0 & \\
\hline Pise 10-07 & Pise 10-07A & $180-400$ & 50 & 68 & -2 & 51.0 & $51.6 \pm 0.6$ \\
\hline
\end{tabular}




$\begin{array}{ccccc} & \text { Pise10-07B } & 180-390 & 50 & 75 \\ \text { Pise10-08 } & \text { Pise10-08A } & 175-385 & 50 & 75 \\ & \text { Pise10-08B } & 175-390 & 50 & 80 \\ \text { Pise10-09 } & \text { Pise10-09A } & 150-390 & 50 & 79 \\ & \text { Pise10-09B } & 150-390 & 50 & 77 \\ \text { Pise10-10 } & \text { Pise10-10A } & 165-395 & 50 & 83 \\ & \text { Pise10-10B } & 165-390 & 50 & 77 \\ \text { Pise10-11 } & \text { Pise10-11A } & 155-400 & 50 & 80 \\ & \text { Pise10-11B } & 155-385 & 50 & 78 \\ \text { Pise10-12 } & \text { Pise10-12A } & 180-390 & 50 & 72 \\ & \text { Pise10-12B } & 150-395 & 50 & 79 \\ \text { Pise10-13 } & \text { Pise10-13A } & 150-395 & 50 & 73 \\ & \text { Pise10-13B } & 150-390 & 50 & 80 \\ \text { Pise10-14 } & \text { Pise10-14A } & 150-400 & 50 & 78 \\ & \text { Pise10-14B } & 150-390 & 50 & 80 \\ \text { Pise10-15 } & \text { Pise10-15A } & 150-395 & 50 & 75 \\ & \text { Pise10-15B } & 150-390 & 50 & 75 \\ \text { Pise10-16 } & \text { Pise10-16A } & 150-395 & 50 & 76 \\ & \text { Pise10-16B } & 150-390 & 50 & 75\end{array}$

$\begin{array}{ll}52.2 & \\ 52.2 & 52.3 \pm 0.1 \\ 52.3 & \\ 47.1 & 47.8 \pm 0.7 \\ 48.5 & \\ 47.6 & 48.8 \pm 1.2 \\ 50.0 & \\ 45.7 & 46.7 \pm 1.0 \\ 47.7 & \\ 48.4 & 49.6 \pm 1.2 \\ 50.7 & \\ 52.3 & 52.2 \pm 0.1 \\ 52.1 & \\ 52.8 & 53.1 \pm 0.3 \\ 53.3 & \\ 52.0 & 51.4 \pm 0.7 \\ 50.7 & \\ 50.9 & 51.1 \pm 0.2 \\ 51.2 & \end{array}$

Pise02, Pisa, Oratory of San Bernardino, [1479-1490] AD, (12/12/11)*

$\begin{array}{llllllll}\text { Pise02-01 } & \text { Pise02-01A } & 180-400 & 50 & 73 & 0 & 46.9 & 48.0 \pm 1.1 \\ & \text { Pise02-01B } & 140-385 & 50 & 80 & 3 & 49.0 & \\ \text { Pise02-02 } & \text { Pise02-02A } & 180-400 & 50 & 85 & -2 & 46.2 & 46.9 \pm 0.7 \\ & \text { Pise02-02B } & 140-395 & 50 & 82 & -2 & 47.6 & \\ \text { Pise02-03 } & \text { Pise02-03C } & 135-380 & 50 & 67 & -4 & 51.9 & 51.4 \pm 0.6 \\ & \text { Pise02-03D } & 135-385 & 50 & 68 & 1 & 50.8 & \\ \text { Pise02-04 } & \text { Pise02-04A } & 170-420 & 50 & 95 & 1 & 46.9 & 47.9 \pm 1.0 \\ & \text { Pise02-04B } & 145-400 & 50 & 94 & -4 & 48.9 & \\ \text { Pise02-05 } & \text { Pise02-05A } & 165-420 & 50 & 85 & -3 & 47.0 & 47.9 \pm 0.9 \\ & \text { Pise02-05B } & 140-385 & 50 & 83 & -2 & 48.8 & \\ \text { Pise02-06 } & \text { Pise02-06A } & 160-410 & 50 & 91 & -1 & 46.6 & 47.5 \pm 0.9 \\ & \text { Pise02-06B } & 140-385 & 50 & 91 & -2 & 48.4 & \\ \text { Pise02-07 } & \text { Pise02-07A } & 165-400 & 50 & 78 & -2 & 49.7 & 49.6 \pm 0.2 \\ & \text { Pise02-07B } & 150-365 & 50 & 80 & -2 & 49.4 & \\ \text { Pise02-08 } & \text { Pise02-08A } & 150-400 & 50 & 57 & -5 & 51.1 & 51.0 \pm 0.1 \\ & \text { Pise02-08B } & 140-395 & 50 & 75 & -2 & 50.9 & \\ \text { Pise02-09 } & \text { Pise02-09B } & 140-395 & 50 & 82 & 0 & 48.8 & 48.9 \pm 0.1 \\ & \text { Pise02-09C } & 135-385 & 50 & 82 & 0 & 49.0 & \\ \text { Pise02-10 } & \text { Pise02-10A } & 150-400 & 50 & 89 & -4 & 45.3 & 45.8 \pm 0.5 \\ & \text { Pise02-10B } & 145-400 & 50 & 89 & -3 & 46.2 & \\ \text { Pise02-11 } & \text { Pise02-11A } & 160-400 & 50 & 67 & -2 & 48.9 & 49.9 \pm 1.0\end{array}$

Pise09, Pisa, New Citadel - Sangallo bastion, [1531-1533] AD, (12/5/5)*

\begin{tabular}{|c|c|c|c|c|c|c|c|}
\hline \multirow[t]{3}{*}{ Pise09-02 } & Pise09-02A & $150-400$ & 50 & 68 & -7 & 50.3 & $51.1 \pm 1.1$ \\
\hline & Pise09-02B & $170-400$ & 50 & 68 & -6 & 52.4 & \\
\hline & Pise09-02C & $150-405$ & 50 & 71 & 2 & 50.6 & \\
\hline \multirow[t]{3}{*}{ Pise09-04 } & Pise09-04A & $180-465$ & 50 & 84 & 2 & 50.2 & $51.6 \pm 1.3$ \\
\hline & Pise09-04B & $185-400$ & 50 & 82 & -7 & 51.9 & \\
\hline & Pise09-04D & $175-390$ & 50 & 80 & -7 & 52.7 & \\
\hline \multirow[t]{3}{*}{ Pise09-08 } & Pise09-08A & $155-410$ & 50 & 83 & -7 & 52.8 & $51.9 \pm 0.9$ \\
\hline & Pise09-08B & $150-400$ & 50 & 83 & -1 & 51.1 & \\
\hline & Pise09-08C & $150-405$ & 50 & 87 & -3 & 51.9 & \\
\hline \multirow[t]{3}{*}{ Pise09-10 } & Pise09-10A & $150-410$ & 50 & 79 & 2 & 50.9 & $52.5 \pm 1.4$ \\
\hline & Pise09-10B & $150-390$ & 50 & 79 & -2 & 53.3 & \\
\hline & Pise09-10C & $150-405$ & 50 & 82 & 0 & 53.2 & \\
\hline \multirow[t]{3}{*}{ Pise09-12 } & Pise09-12A & $150-410$ & 50 & 94 & -3 & 49.9 & $51.5 \pm 1.4$ \\
\hline & Pise09-12B & $150-390$ & 50 & 76 & -4 & 52.5 & \\
\hline & Pise09-12D & $150-395$ & 50 & 87 & -5 & 52.2 & \\
\hline \multicolumn{8}{|c|}{ Pise01, Pisa, "Le Bocchette di Putignano", 1558 AD, (10/3/3)* } \\
\hline Pise01-07 & Pise01-07A & $175-400$ & 50 & 60 & 0 & 46.7 & $47.1 \pm 0.4$ \\
\hline
\end{tabular}




\begin{tabular}{|c|c|c|c|c|c|c|c|}
\hline & Pise01-07B & $175-445$ & 50 & 70 & 5 & 47.1 & \\
\hline & Pise01-07C & $175-450$ & 50 & 70 & 4 & 47.4 & \\
\hline \multirow{3}{*}{ Pise01-08 } & Pise01-08A & $150-400$ & 50 & 70 & -4 & 50.7 & $51.3 \pm 1.1$ \\
\hline & Pise01-08B & $140-395$ & 50 & 74 & -3 & 52.5 & \\
\hline & Pise01-08C & $175-395$ & 50 & 72 & -5 & 50.6 & \\
\hline \multirow[t]{3}{*}{ Pise01-10 } & Pise01-10A & $150-400$ & 50 & 72 & 2 & 51.8 & $53.0 \pm 1.1$ \\
\hline & Pise01-10B & $140-395$ & 50 & 69 & 4 & 53.1 & \\
\hline & Pise01-10D & $155-395$ & 50 & 69 & -1 & 54.0 & \\
\hline
\end{tabular}

Pise08, Pisa, Medici shipyard (Arsenal), 1588 AD, (15/11/6)*

$\begin{array}{lllll}\text { Pise08-03 Pise08-03A } & 155-400 & 50 & 80\end{array}$

$\begin{array}{lllll} & \text { Pise08-03B } & 160-395 & 50 & 78 \\ \text { Pise08-04 } & \text { Pise08-04A } & 150-400 & 50 & 76\end{array}$

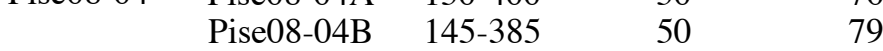

Pise08-05 Pise08-05A $135-390 \quad 50 \quad 82$

$\begin{array}{lllll} & \text { Pise08-05B } & 135-390 & 50 & 84\end{array}$

$\begin{array}{lllll}\text { Pise08-06 Pise08-06A } & 150-400 & 50 & 79\end{array}$

$\begin{array}{lllll} & \text { Pise08-06B } & 145-385 & 50 & 82 \\ \text { Pise08-08 } & \text { Pise08-08A } & 150-395 & 50 & 61\end{array}$

$\begin{array}{lllll} & \text { Pise08-08B } & 150-420 & 50 & 70 \\ \text { Pise08-11 } & \text { Pise08-11A } & 150-390 & 50 & 82\end{array}$

Pise08-11B $145-385 \quad 50 \quad 81$

$\begin{array}{ll}54.9 & 55.1 \pm 0.2 \\ 55.2 & \\ 52.0 & 52.6 \pm 0.6 \\ 53.2 & \\ 50.6 & 51.0 \pm 0.4 \\ 51.3 & \\ 54.9 & 54.8 \pm 0.2 \\ 54.6 & \\ 51.8 & 51.4 \pm 0.4 \\ 51.0 & \\ 53.4 & 53.6 \pm 0.2 \\ 53.8 & \end{array}$

Pise06, Pisa, Medici Aqueduct - Arch, 1595 AD, (15/15/12)*

$\begin{array}{lllll}\text { Pise06-01 Pise06-01A } & 150-400 & 55 & 84\end{array}$

$\begin{array}{lllll} & \text { Pise06-01B } & 150-390 & 55 & 81 \\ \text { Pise06-02 } & \text { Pise06-02A } & 165-400 & 55 & 83\end{array}$

$\begin{array}{llll} & \text { Pise06-02B } & 165-390 & 50\end{array}$

Pise06-03 Pise06-03A $150-400 \quad 55 \quad 80$

$\begin{array}{llll}\text { Pise06-03B } & 150-390 & 55 & 82\end{array}$

Pise06-04 Pise06-04A $150-400 \quad 55 \quad 85$

$\begin{array}{llll}\text { Pise06-04A } & 150-400 & 55 & 85 \\ \text { Pise06-04B } & 150-390 & 55 & 86\end{array}$

$\begin{array}{llll}\text { Pise06-05 Pise06-05A } & 150-400 & 55 & 81\end{array}$

Pise06-05B $150-390 \quad 55 \quad 80$

Pise06-07 Pise06-07A $150-400 \quad 55$

$\begin{array}{llll}\text { Pise06-07B } & 150-390 & 55 & 85\end{array}$

Pise06-08 Pise06-08A $150-400 \quad 55$

$\begin{array}{llll}\text { Pise06-08B } & 150-390 & 55 & 80\end{array}$

Pise06-09 Pise06-09A $150-400 \quad 55 \quad 84$

Pise06-09B $150-390 \quad 55 \quad 83$

$\begin{array}{lllll}\text { Pise06-10 Pise06-10A } & 150-400 & 55 & 80\end{array}$

$\begin{array}{lllll} & \text { Pise06-10B } & 150-390 & 55 & 86 \\ \text { Pise06-11 } & \text { Pise06-11A } & 150-400 & 55 & 79\end{array}$

Pise06-11B $150-390 \quad 55 \quad 82$

$\begin{array}{llll}\text { Pise06-12 Pise06-12B } & 150-385 & 55 & 88\end{array}$

Pise06-12D $150-395 \quad 55 \quad 93$

Pise06-13 Pise06-13A 150-400 55

Pise06-13B 150-390 55

$54.6 \pm 0.2$

$52.1 \pm 1.2$

53.3

53.7

56.4

51.9

53.9

54.7

55.4

54.5

54.7

52.3

54.2

53.8

56.1

55.1

55.9

54.9

55.1

54.1

52.5

56.2

57.4

$55.1 \pm 1.4$

$52.9 \pm 1.0$

$55.1 \pm 0.4$

$54.6 \pm 0.1$

$53.3 \pm 1.0$

$55.0 \pm 1.2$

$55.5 \pm 0.4$

$55.0 \pm 0.1$

$53.3 \pm 0.8$

$56.8 \pm 0.6$

Pise07, Pisa, Santo Stefano dei Cavalieri church, [1683-1691] AD, (12/12/12)*

$\begin{array}{llllllll}\text { Pise07-01 } & \text { Pise07-01A } & 150-400 & 45 & 76 & 2 & 49.9 & 50.8 \pm 0.9 \\ & \text { Pise07-01B } & 150-390 & 50 & 78 & 4 & 51.6 & \\ \text { Pise07-02 } & \text { Pise07-02A } & 150-390 & 45 & 86 & 0 & 50.3 & 51.4 \pm 1.1 \\ & \text { Pise07-02B } & 150-395 & 50 & 82 & 1 & 52.5 & \\ \text { Pise07-03 } & \text { Pise07-03A } & 145-400 & 45 & 74 & 1 & 50.2 & 51.4 \pm 1.2 \\ & \text { Pise07-03B } & 170-395 & 50 & 81 & 2 & 52.6 & \\ \text { Pise07-04 } & \text { Pise07-04A } & 150-400 & 50 & 86 & 3 & 50.8 & 50.6 \pm 0.3 \\ & \text { Pise07-04B } & 145-395 & 50 & 87 & -2 & 50.3 & \\ \text { Pise07-05 } & \text { Pise07-05A } & 150-400 & 50 & 85 & -2 & 50.8 & 51.2 \pm 0.4 \\ & \text { Pise07-05B } & 140-395 & 50 & 85 & 0 & 51.6 & 46.6 \pm 0.3 \\ \text { Pise07-06 } & \text { Pise07-06A } & 175-395 & 50 & 81 & -5 & 46.8 & 46.6 \pm 0.3 \\ & \text { Pise07-06B } & 190-395 & 50 & 81 & 0 & 46.3 & \\ \text { Pise07-07 } & \text { Pise07-07A } & 150-400 & 50 & 79 & -4 & 50.5 & 50.5 \pm 0.1\end{array}$




\begin{tabular}{|c|c|c|c|c|c|c|c|}
\hline & Pise07-07B & $145-395$ & 50 & 80 & -2 & 50.4 & \\
\hline \multirow{2}{*}{ Pise07-08 } & Pise07-08A & $150-400$ & 50 & 84 & 0 & 49.4 & $50.2 \pm 0.8$ \\
\hline & Pise07-08B & $145-400$ & 50 & 82 & 1 & 51.0 & \\
\hline \multirow[t]{2}{*}{ Pise07-09 } & Pise07-09A & $150-400$ & 50 & 82 & 2 & 51.4 & $52.2 \pm 0.8$ \\
\hline & Pise07-09B & $140-395$ & 50 & 82 & 0 & 52.9 & \\
\hline \multirow[t]{2}{*}{ Pise07-10 } & Pise07-10A & $150-390$ & 50 & 89 & -1 & 51.3 & $51.2 \pm 0.2$ \\
\hline & Pise07-10B & $145-395$ & 50 & 90 & 1 & 51.0 & \\
\hline \multirow[t]{2}{*}{ Pise07-11 } & Pise07-11A & $140-395$ & 50 & 82 & -3 & 48.2 & $47.2 \pm 1.1$ \\
\hline & Pise07-11B & $155-385$ & 50 & 70 & 1 & 46.1 & \\
\hline \multirow[t]{2}{*}{ Pise07-12 } & Pise07-12A & $150-395$ & 50 & 88 & 4 & 48.5 & $49.3 \pm 0.8$ \\
\hline & Pise07-12B & $140-395$ & 50 & 90 & 3 & 50.1 & \\
\hline \multicolumn{8}{|c|}{ Pise03, Asciano Pisano, Medici Aqueduct - Cistern, [1613-1617] AD, (12/11/10)* } \\
\hline \multirow[t]{2}{*}{ Pise03-01 } & Pise03-01A & $155-420$ & 50 & 78 & 1 & 54.4 & $55.0 \pm 0.6$ \\
\hline & Pise03-01B & $150-400$ & 50 & 78 & -4 & 55.6 & \\
\hline \multirow[t]{2}{*}{ Pise03-02 } & Pise03-02A & $150-400$ & 50 & 73 & 4 & 53.9 & $55.2 \pm 1.3$ \\
\hline & Pise03-02B & $150-385$ & 50 & 75 & -2 & 56.4 & \\
\hline \multirow[t]{2}{*}{ Pise03-03 } & Pise03-03A & $150-400$ & 55 & 80 & 0 & 54.2 & $54.1 \pm 0.1$ \\
\hline & Pise03-03B & $150-385$ & 55 & 80 & 1 & 54.0 & \\
\hline \multirow[t]{2}{*}{ Pise03-05 } & Pise03-05A & $150-400$ & 55 & 79 & -1 & 56.0 & $56.5 \pm 0.5$ \\
\hline & Pise03-05B & $150-385$ & 55 & 74 & -2 & 56.9 & \\
\hline \multirow[t]{2}{*}{ Pise03-06 } & Pise03-06A & $150-400$ & 55 & 81 & 0 & 54.9 & $55.8 \pm 0.9$ \\
\hline & Pise03-06C & $150-380$ & 55 & 82 & -3 & 56.6 & \\
\hline \multirow[t]{2}{*}{ Pise03-07 } & Pise03-07A & $150-400$ & 55 & 81 & -1 & 54.4 & $55.7 \pm 1.3$ \\
\hline & Pise03-07B & $145-385$ & 55 & 80 & -3 & 57.0 & \\
\hline \multirow[t]{2}{*}{ Pise03-08 } & Pise03-08B & $135-385$ & 55 & 80 & 0 & 57.5 & $58.1 \pm 0.6$ \\
\hline & Pise03-08C & $135-380$ & 55 & 79 & 2 & 58.7 & \\
\hline \multirow[t]{2}{*}{ Pise03-09 } & Pise03-09A & $150-400$ & 55 & 78 & -2 & 52.6 & $52.4 \pm 0.3$ \\
\hline & Pise03-09B & $150-385$ & 55 & 78 & 2 & 52.1 & \\
\hline \multirow[t]{2}{*}{ Pise03-10 } & Pise03-10A & $150-400$ & 55 & 87 & -5 & 53.1 & $52.1 \pm 1.1$ \\
\hline & Pise03-10B & $150-390$ & 55 & 87 & -2 & 51.0 & \\
\hline Pise03-11 & Pise03-11A & $150-400$ & 55 & 72 & 1 & 54.7 & $54.7 \pm 0.0$ \\
\hline & Pise03-11B & $150-390$ & 55 & 79 & 2 & 54.7 & \\
\hline Pise04, As & Ino Pisano, $N$ & dici Aque & Pill & -161 & $2 / 1$ & & \\
\hline Pise04-01 & Pise04-01A & $150-400$ & 55 & 93 & -2 & 51.6 & $53.0 \pm 1.2$ \\
\hline & Pise04-01B & $140-390$ & 55 & 89 & 1 & 53.7 & \\
\hline & Pise04-01D & $140-380$ & 55 & 93 & 2 & 53.8 & \\
\hline Pise04-02 & Pise04-02A & $150-400$ & 55 & 81 & -3 & 51.2 & $52.4 \pm 1.2$ \\
\hline & Pise04-02B & $170-390$ & 55 & 84 & -3 & 53.6 & \\
\hline Pise04-04 & Pise04-04A & $150-400$ & 55 & 81 & 1 & 54.2 & $55.5 \pm 1.3$ \\
\hline & Pise04-04B & $140-390$ & 55 & 87 & 1 & 56.8 & \\
\hline & Pise04-04C & $140-395$ & 55 & 84 & -1 & 55.6 & \\
\hline Pise04-05 & Pise04-05A & $150-400$ & 55 & 85 & 0 & 56.3 & $56.9 \pm 1.0$ \\
\hline & Pise04-05B & $140-390$ & 55 & 82 & -3 & 56.4 & \\
\hline & Pise04-05D & $150-385$ & 55 & 88 & 0 & 58.1 & \\
\hline Pise04-06 & Pise04-06A & $170-390$ & 55 & 80 & -5 & 49.8 & $50.5 \pm 0.7$ \\
\hline & Pise04-06B & $150-395$ & 55 & 83 & -3 & 51.1 & \\
\hline Pise04-07 & Pise04-07A & $160-400$ & 55 & 82 & -4 & 56.5 & $56.8 \pm 0.2$ \\
\hline & Pise04-07B & $165-390$ & 55 & 79 & -5 & 56.9 & \\
\hline & Pise04-07C & $165-395$ & 55 & 82 & -4 & 56.9 & \\
\hline Pise04-10 & Pise04-10A & $150-400$ & 55 & 79 & 2 & 55.9 & $56.5 \pm 0.6$ \\
\hline & Pise04-10B & $150-390$ & 55 & 84 & -1 & 57.1 & \\
\hline Pise04-11 & Pise04-11A & $150-400$ & 55 & 80 & 0 & 54.8 & $55.7 \pm 0.9$ \\
\hline & Pise04-11B & $150-390$ & 55 & 86 & -2 & 56.5 & \\
\hline Pise04-12 & Pise04-12A & $150-400$ & 55 & 88 & -5 & 55.8 & $56.6 \pm 0.8$ \\
\hline & Pise04-12B & $150-390$ & 55 & 88 & -3 & 57.4 & \\
\hline Pise05, As & Ino Pisano, & dici Aque & Pill & $\mathbf{A D}$ & & & \\
\hline Pise05-01 & Pise05-01A & $150-400$ & 50 & 76 & -1 & 53.0 & $52.9 \pm 0.1$ \\
\hline & Pise05-01B & $150-370$ & 50 & 77 & -2 & 52.8 & \\
\hline Pise05-02 & Pise05-02A & $150-400$ & 50 & 87 & 2 & 50.5 & $51.0 \pm 0.5$ \\
\hline & Pise05-02B & $150-400$ & 50 & 83 & 1 & 51.5 & \\
\hline
\end{tabular}




\begin{tabular}{|c|c|c|c|c|c|c|c|}
\hline \multirow[t]{2}{*}{ Pise05-03 } & Pise05-03A & $150-400$ & 50 & 79 & -4 & 52.8 & $53.4 \pm 0.6$ \\
\hline & Pise05-03B & $150-380$ & 50 & 75 & -6 & 53.9 & \\
\hline \multirow[t]{2}{*}{ Pise05-04 } & Pise05-04A & $150-400$ & 50 & 81 & -4 & 55.3 & $54.3 \pm 1.1$ \\
\hline & Pise05-04B & $150-380$ & 50 & 82 & -4 & 53.2 & \\
\hline \multirow[t]{2}{*}{ Pise05-05 } & Pise05-05A & $150-400$ & 50 & 89 & 2 & 51.1 & $52.0 \pm 0.9$ \\
\hline & Pise05-05B & $150-385$ & 50 & 89 & -1 & 52.9 & \\
\hline \multirow[t]{2}{*}{ Pise05-06 } & Pise05-06A & $150-400$ & 50 & 80 & 0 & 51.2 & $52.1 \pm 0.8$ \\
\hline & Pise05-06B & $150-385$ & 50 & 80 & 1 & 52.9 & \\
\hline \multirow[t]{2}{*}{ Pise05-07 } & Pise05-07A & $150-400$ & 50 & 83 & 0 & 54.3 & $55.0 \pm 0.7$ \\
\hline & Pise05-07B & $150-390$ & 50 & 82 & -2 & 55.6 & \\
\hline \multirow[t]{2}{*}{ Pise05-09 } & Pise05-09A & $150-400$ & 50 & 84 & 3 & 54.9 & $55.5 \pm 0.6$ \\
\hline & Pise05-09B & $150-390$ & 50 & 84 & 0 & 56.1 & \\
\hline \multirow[t]{2}{*}{ Pise05-10 } & Pise05-10B & $140-385$ & 50 & 88 & -3 & 53.4 & $53.3 \pm 01$ \\
\hline & Pise05-10C & $140-385$ & 50 & 84 & -3 & 53.2 & \\
\hline \multirow[t]{2}{*}{ Pise05-11 } & Pise05-11A & $150-400$ & 50 & 81 & -1 & 54.6 & $54.9 \pm 0.3$ \\
\hline & Pise05-11B & $160-390$ & 50 & 79 & -2 & 55.1 & \\
\hline \multirow[t]{2}{*}{ Pise05-12 } & Pise05-12A & $175-375$ & 50 & 68 & 4 & 51.2 & $50.6 \pm 0.7$ \\
\hline & Pise05-12B & $170-390$ & 50 & 75 & -7 & 49.9 & \\
\hline \multirow[t]{2}{*}{ Pise05-13 } & Pise05-13A & $135-380$ & 50 & 72 & -6 & 50.9 & $52.1 \pm 1.2$ \\
\hline & Pise05-13C & $140-380$ & 50 & 73 & 1 & 53.3 & \\
\hline \multirow[t]{2}{*}{ Pise05-14 } & Pise05-14A & $150-395$ & 50 & 79 & 4 & 52.4 & $53.7 \pm 1.3$ \\
\hline & Pise05-14B & $150-385$ & 50 & 80 & -1 & 55.0 & \\
\hline \multicolumn{8}{|c|}{ Tosc03, Calcinaia, Castle - Medieval Tower, [1260-1287] AD, (11/10/5)* } \\
\hline \multirow[t]{2}{*}{ Tosc03-05 } & Tosc03-05A & $190-445$ & 50 & 78 & 5 & 50.7 & $50.1 \pm 0.7$ \\
\hline & Tosc03-05B & $190-435$ & 50 & 79 & -6 & 49.4 & \\
\hline \multirow[t]{2}{*}{ Tosc03-06 } & Tosc03-06A & $140-445$ & 50 & 81 & 7 & 50.6 & $49.6 \pm 1.1$ \\
\hline & Tosc03-06B & $135-425$ & 50 & 82 & 3 & 48.5 & \\
\hline \multirow{2}{*}{ Tosc03-07 } & Tosc03-07A & $220-445$ & 50 & 70 & 3 & 52.0 & $52.4 \pm 0.4$ \\
\hline & Tosc03-07B & $220-435$ & 50 & 75 & 0 & 52.7 & \\
\hline \multirow[t]{2}{*}{ Tosc03-08 } & Tosc03-08A & $140-445$ & 50 & 75 & 4 & 55.1 & $56.0 \pm 0.9$ \\
\hline & Tosc03-08B & $160-435$ & 50 & 72 & 5 & 56.8 & \\
\hline \multirow[t]{2}{*}{ Tosc03-10 } & Tosc03-10A & $140-445$ & 50 & 84 & -3 & 53.3 & $53.3 \pm 0.0$ \\
\hline & Tosc $03-10 \mathrm{~B}$ & $150-435$ & 50 & 75 & -3 & 53.2 & \\
\hline \multicolumn{8}{|c|}{ Tosc04, Marti, Santa Maria Novella church, 1331 AD, (12/11/10)* } \\
\hline Tosc04-02 & Tosc04-02A & $170-400$ & 55 & 71 & -4 & 49.0 & $48.3 \pm 0.7$ \\
\hline & Tosc04-02B & $155-380$ & 55 & 66 & -7 & 47.6 & \\
\hline & Tosc04-02E & $155-395$ & 55 & 70 & -2 & 48.3 & \\
\hline Tosc04-03 & Tosc04-03A & $155-400$ & 55 & 85 & -3 & 46.1 & $47.1 \pm 1.0$ \\
\hline & Tosc04-03B & $135-380$ & 55 & 86 & -2 & 48.1 & \\
\hline Tosc04-05 & Tosc04-05A & $140-395$ & 55 & 86 & 2 & 55.1 & $55.9 \pm 0.8$ \\
\hline & Tosc04-05B & $140-390$ & 45 & 86 & -4 & 56.6 & \\
\hline Tosc04-06 & Tosc04-06A & $140-395$ & 55 & 85 & 4 & 52.1 & $53.0 \pm 0.9$ \\
\hline & Tosc04-06B & $140-390$ & 55 & 81 & -5 & 53.9 & \\
\hline Tosc04-07 & Tosc04-07A & $140-395$ & 55 & 89 & -2 & 55.1 & $55.3 \pm 0.2$ \\
\hline & Tosc04-07B & $140-390$ & 55 & 89 & -5 & 55.4 & \\
\hline Tosc04-08 & Tosc04-08A & $140-395$ & 55 & 82 & -1 & 54.1 & $54.3 \pm 0.2$ \\
\hline & Tosc04-08B & $135-380$ & 55 & 81 & 1 & 54.5 & \\
\hline Tosc04-09 & Tosc04-09A & $140-395$ & 55 & 81 & 2 & 48.1 & $48.8 \pm 0.7$ \\
\hline & Tosc04-09B & $135-380$ & 55 & 82 & -1 & 49.5 & \\
\hline Tosc04-10 & Tosc04-10A & $140-395$ & 55 & 85 & 2 & 53.5 & $54.6 \pm 1.1$ \\
\hline & Tosc04-10B & $145-380$ & 55 & 83 & -4 & 55.7 & \\
\hline Tosc04-11 & Tosc04-11A & $140-395$ & 55 & 83 & 4 & 54.8 & $55.1 \pm 0.3$ \\
\hline & Tosc04-11B & $140-380$ & 55 & 85 & 2 & 55.3 & \\
\hline Tosc04-12 & Tosc04-12A & $140-395$ & 55 & 79 & 4 & 50.3 & $51.4 \pm 1.1$ \\
\hline & Tosc04-12B & $140-390$ & 55 & 77 & -1 & 52.4 & \\
\hline
\end{tabular}

